4

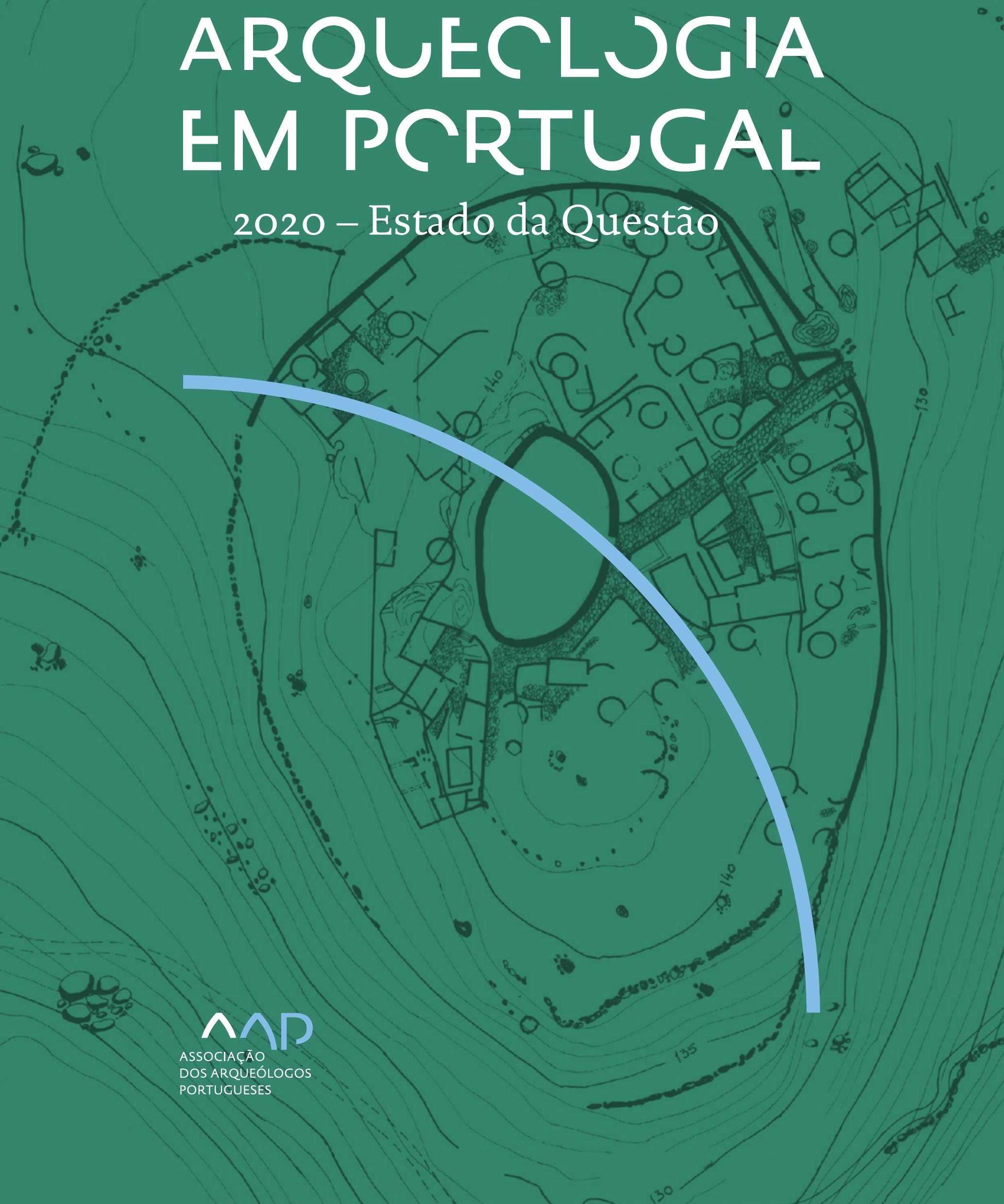


Coordenação editorial: José Morais Arnaud, César Neves e Andrea Martins Design gráfico: Flatland Design

AAP - ISBN: 978-972-9451-89-8

CITCEM - ISBN: 978-989-8970-25-1

Associação dos Arqueólogos Portugueses e CITCEM

Lisboa, 2020

O conteúdo dos artigos é da inteira responsabilidade dos autores. Sendo assim a Associação dos Arqueólogos Portugueses declina qualquer responsabilidade por eventuais equívocos ou questões de ordem ética e legal.

Desenho de capa:

Planta do castro de Monte Mozinho (Museu Municipal de Penafiel).

\section{$\hat{\wedge} \mathrm{P}$}

DOS ARQUEÓLOGOS PORTUGUESES

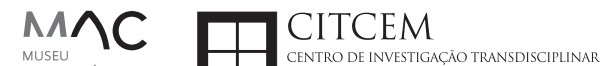
MUSEU
ARQUELLÓGICO
DO CARMO
U.PORTO

FLUP FACULDADE DE LETRAS
UNIVERSIDADE DO PORTO

Apoio

EC para a Ciência 


\section{Índice}

15 Prefácio

José Morais Arnaud

\section{Historiografia e Teoria}

17 Território, comunidade, memória e emoção: a contribuição da história da arqueologia (algumas primeiras e breves reflexões)

Ana Cristina Martins

25 Como descolonizar a arqueologia portuguesa?

Rui Gomes Coelho

41 Arqueologia e Modernidade: uma revisitação pessoal e breve de alguns aspetos da obra homónima de Julian Thomas de 2004

Vítor Oliveira Jorge

57 Dados para a História das Mulheres na Arqueologia portuguesa, dos finais do século XIX aos inícios do século XX: números, nomes e tabelas

Filipa Dimas / Mariana Diniz

73 Retractos da arqueologia portuguesa na imprensa: (in)visibilidades no feminino

Catarina Costeira / Elsa Luís

85 Arqueologia e Arqueólogos no Norte de Portugal Jacinta Bugalhão

101 Vieira Guimarães (1864-1939) e a arqueologia em Tomar: uma abordagem sobre o território e as gentes

João Amendoeira Peixoto / Ana Cristina Martins

115 Os memoráveis? A arqueologia algarvia na imprensa nacional e regional na presente centúria (2001-2019): características, visões do(s) passado(s) e a arqueologia

enquanto marca

Frederico Agosto / João Silva

129 A Evolução da Arqueologia Urbana e a Valorização Patrimonial no Barlavento Algarvio: Os casos de Portimão e Silves

Artur Mateus / Diogo Varandas / Rafael Boavida

\section{Gestão, Valorização e Salvaguarda do Património}

145 O Caderno Reivindicativo e as condições de trabalho em Arqueologia Miguel Rocha / Liliana Matias Carvalho / Regis Barbosa / Mauro Correia / Sara Simões / Jacinta Bugalhão / Sara Brito / Liliana Veríssimo Carvalho / Richard Peace / Pedro Peça / Cézer Santos

155 Os Estudos de Impacte Patrimonial como elemento para uma estratégia sustentável de minimização de impactes no âmbito de reconversões agrícolas Tiago do Pereiro

165 Salvaguarda de Património arqueológico em operações florestais: gestão e sensibilização Filipa Bragança / Gertrudes Zambujo / Sandra Lourenço / Belém Paiva / Carlos Banha / Frederico Tatá Regala / Helena Moura / Jacinta Bugalhão / João Marques / José Correia / Pedro Faria / Samuel Melro

179 Os valores do Património: uma investigação sobre os Sítios Pré-históricos de Arte Rupestre do Vale do Rio Côa e de Siega Verde José Paulo Francisco 
189 Conjugando recursos arqueológicos e naturais para potenciar as visitas ao Geoparque Litoral de Viana do Castelo (Noroeste de Portugal)

Hugo A. Sampaio / Ana M.S. Bettencourt / Susana Marinho / Ricardo Carvalhido

203 Áreas de Potencial Arqueológico na Região do Médio Tejo: Modelo Espacial Preditivo Rita Ferreira Anastácio / Ana Filipa Martins / Luiz Oosterbeek

223 Património Arqueológico e Gestão Territorial: O contributo da Arqueologia para a revisão do PDM de Avis

Ana Cristina Ribeiro

237 A coleção arqueológica do extinto Museu Municipal do Porto - Origens, Percursos e Estudos

Sónia Couto

251 Valpaços - uma nova carta arqueológica

Pedro Pereira / Maria de Fátima Casares Machado

263 Arqueologia na Cidade de Peniche

Adriano Constantino / Luís Rendeiro

273 Arqueologia Urbana: a cidade de Lagos como caso de Estudo Cátia Neto

285 Estratégias de promoção do património cultural subaquático nos Açores. O caso da ilha do Faial

José Luís Neto / José Bettencourt / Luís Borges / Pedro Parreira

297 Carta Arqueológica da Cidade Velha: Uma primeira abordagem

Jaylson Monteiro / Nireide Tavares / Sara da Veiga / Claudino Ramos / Edson Brito /

Carlos Carvalho / Francisco Moreira / Adalberto Tavares

311 Antropologia Virtual: novas metodologias para a análise morfológica e funcional Ricardo Miguel Godinho / Célia Gonçalves

\section{Didáctica da Arqueologia}

327 Como os projetos de Arqueologia podem contribuir para uma comunidade culturalmente mais consciente Alexandra Figueiredo / Claúdio Monteiro / Adolfo Silveira / Ricardo Lopes

337 Educação Patrimonial - Um cidadão esclarecido é um cidadão ativo! Ana Paula Almeida

351 A aproximação da Arqueologia à sala de aula: um caso de estudo no $3^{\circ}$ ciclo do Ensino Básico Luís Serrão Gil

363 Arqueologia 3.o - Pensar e comunicar a Arqueologia para um futuro sustentável Mónica Rolo

377 “Conversa de Arqueólogos" - Divulgar a Arqueologia em tempos de Pandemia Diogo Teixeira Dias

389 Escola Profissional de Arqueologia: desafios e oportunidades Susana Nunes / Dulcineia Pinto / Júlia Silva / Ana Mascarenhas

399 Os Museus de Arqueologia e os Jovens: a oferta educativa para o público adolescente Beatriz Correia Barata / Leonor Medeiros

411 O museu universitário como mediador entre a ciência e a sociedade: o exemplo da secção de arqueologia no Museu de História Natural e da Ciência da Universidade do Porto (MHNC-UP)

Rita Gaspar 
421 Museu de Lanifícios: Real Fábrica de Panos. Atividades no âmbito da Arqueologia Beatriz Correia Barata / Rita Salvado

427 Arqueologia Pública e o caso da localidade da Mata (Torres Novas) Cláudia Manso / Ana Rita Ferreira / Cristiana Ferreira / Vanessa Cardoso Antunes

431 Do sítio arqueológico ao museu: um percurso (também) didático Lídia Fernandes

447 Estão todos convidados para a Festa! E para dançar também... O projecto do Serviço Educativo do Museu Arqueológico do Carmo na $5^{\underline{a}}$ Edição da Festa da Arqueologia Rita Pires dos Santos

459 O “Clã de Carenque”, um projeto didático de arqueologia Eduardo Gonzalez Rocha

469 Mediação cultural: peixe que puxa carroça nas Ruínas Romanas de Troia Inês Vaz Pinto / Ana Patrícia Magalhães / Patrícia Brum / Filipa Santos

481 Didática Arqueológica, experiências do Projeto Mértola Vila Museu Maria de Fátima Palma / Clara Rodrigues / Susana Gómez / Lígia Rafael

\section{Arte Rupestre}

497 Os inventários de arte rupestre em Portugal Mila Simões de Abreu

513 O projeto FIRST-ART - conservação, documentação e gestão das primeiras manifestações de arte rupestre no Sudoeste da Península Ibérica: as grutas do Escoural e Maltravieso Sara Garcês / Hipólito Collado / José Julio García Arranz / Luiz Oosterbeek / António Carlos Silva / Pierluigi Rosina / Hugo Gomes / Anabela Borralheiro Pereira / George Nash / Esmeralda Gomes / Nelson Almeida / Carlos Carpetudo

523 Trabalhos de documentação de arte paleolítica realizados no âmbito do projeto PalæoCôa André Tomás Santos / António Fernando Barbosa / Luís Luís / Marcelo Silvestre / Thierry Aubry

537 Imagens fantasmagóricas, silhuetas elusivas: as figuras humanas na arte do Paleolítico Superior da região do Côa Mário Reis

$55^{1}$ Os motivos zoomórficos representados nas placas de tear de Vila Nova de São Pedro (Azambuja, Portugal) Andrea Martins / César Neves / José M. Arnaud / Mariana Diniz

571 Arte Rupestre do Monte de Góios (Lanhelas, Caminha). Síntese dos resultados dos trabalhos efectuados em 2007-2009 Mário Varela Gomes

599 Gravuras rupestres de barquiformes no Monte de S. Romão, Guimarães, Noroeste de Portugal Daniela Cardoso

613 Círculos segmentados gravados na Bacia do Rio Lima (Noroeste de Portugal): contributos para o seu estudo Diogo Marinho / Ana M.S. Bettencourt / Hugo Aluai Sampaio

631 Equídeos gravados no curso inferior do Rio Mouro, Monção (NW Portugal). Análise preliminar Coutinho, L.M. / Bettencourt, A.M.S / Sampaio, Hugo A.S

645 Paletas na Arte Rupestre do Noroeste de Portugal. Inventário preliminar Bruna Sousa Afonso / Ana M. S. Bettencourt / Hugo A. Sampaio 


\section{Pré-História}

661 O projeto Miño/Minho: balanço de quatro anos de trabalhos arqueológicos Sérgio Monteiro-Rodrigues / João Pedro Cunha-Ribeiro / Eduardo Méndez-Quintas / Carlos Ferreira / Pedro Xavier / José Meireles / Alberto Gomes / Manuel Santonja / Alfredo Pérez-González

677 A ocupação paleolítica da margem esquerda do Baixo Minho: a indústria lítica do sítio de Pedreiras 2 (Monção, Portugal) e a sua integração no contexto regional Carlos Ferreira / João Pedro Cunha-Ribeiro / Sérgio Monteiro-Rodrigues / Eduardo Méndez-Quintas / Pedro Xavier / José Meireles / Alberto Gomes / Manuel Santonja / Alfredo Pérez-González

693 O sítio acheulense do Plistocénico médio da Gruta da Aroeira Joan Daura / Montserrat Sanz / Filipa Rodrigues / Pedro Souto / João Zilhão

703 As sociedades neandertais no Barlavento algarvio: modelos preditivos com recurso aos SIG

Daniela Maio

715 A utilização de quartzo durante o Paleolítico Superior no território dos vales dos rios Vouga e Côa

Cristina Gameiro / Thierry Aubry / Bárbara Costa / Sérgio Gomes / Luís Luís / Carmen Manzano / André Tomás Santos

733 Uma perspetiva diacrónica da ocupação do concheiro do Cabeço da Amoreira (Muge, Portugal) a partir da tecnologia lítica Joana Belmiro / João Cascalheira / Célia Gonçalves

745 Novos dados sobre a Pré-história Antiga no concelho de Palmela. A intervenção arqueológica no sítio do Poceirão I

Michelle Teixeira Santos

757 Problemas em torno de Datas Absolutas Pré-Históricas no Norte do Alentejo Jorge de Oliveira

771 Povoamento pré-histórico nas áreas montanhosas do NO de Portugal: o Abrigo 1 de Vale de Cerdeira Pedro Xavier / José Meireles / Carlos Alves

783 Apreciação do povoamento do Neolítico Inicial na Baixa Bacia do Douro. A Lavra I (Serra da Aboboreira) como caso de estudo Maria de Jesus Sanches

797 O Processo de Neolitização na Plataforma do Mondego: os dados do Sector C do Outeiro dos Castelos de Beijós (Carregal do Sal)

João Carlos de Senna-Martinez / José Manuel Quintã Ventura / Andreia Carvalho / Cíntia Maurício

823 Novos trabalhos na Lapa da Bugalheira (Almonda, Torres Novas) Filipa Rodrigues / Pedro Souto / Artur Ferreira / Alexandre Varanda / Luís Gomes / Helena Gomes / João Zilhão

837 A pedra polida e afeiçoada do sítio do Neolítico médio da Moita do Ourives (Benavente, Portugal)

César Neves

857 Casal do Outeiro (Encarnação, Mafra): novos contributos para o conhecimento do povoamento do Neolítico final na Península de Lisboa.

Cátia Delicado / Carlos Maneira e Costa / Marta Miranda / Ana Catarina Sousa

873 Stresse infantil, morbilidade e mortalidade no sítio arqueológico do Neolítico Final/ Calcolítico ( $4^{\circ}$ e $3^{\circ}$ milénio a.C.) do Monte do Carrascal 2 (Ferreira do Alentejo, Beja) Liliana Matias de Carvalho / Sofia N. Wasterlain 
885 Come together: O Conjunto Megalítico das Motas (Monção, Viana do Castelo) e as expressões Campaniformes do Alto Minho Ana Catarina Basílio / Rui Ramos

899 Trabalhos arqueológicos no sítio Calcolítico da Pedreira do Poio Carla Magalhães / João Muralha / Mário Reis / António Batarda Fernandes

913 O sítio arqueológico de Castanheiro do Vento. Da arquitectura do sítio à arquitectura de um território João Muralha Cardoso

925 Estudo zooarqueológico das faunas do Calcolítico final de Vila Nova de São Pedro (Azambuja, Portugal): Campanhas de 2017 e 2018 Cleia Detry / Ana Catarina Francisco / Mariana Diniz / Andrea Martins / César Neves / José Morais Arnaud

943 As faunas depositadas no Museu Arqueológico do Carmo provenientes de Vila Nova de São Pedro (Azambuja): as campanhas de 1937 a 1967 Ana Catarina Francisco / Cleia Detry / César Neves / Andrea Martins / Mariana Diniz / José Morais Arnaud

959 Análise funcional de material lítico em sílex do castro de Vila Nova de S. Pedro (Azambuja, Portugal): uma primeira abordagem Rafael Lima

971 O recinto da Folha do Ouro 1 (Serpa) no contexto dos recintos de fossos calcolíticos alentejanos

António Carlos Valera / Tiago do Pereiro / Pedro Valério / António M. Monge Soares

\section{Proto-História}

987 Produção de sal marinho na Idade do Bronze do noroeste Português. Alguns dados para uma reflexão

Ana M. S. Bettencourt / Sara Luz / Nuno Oliveira / Pedro P. Simões / Maria Isabel C. Alves / Emílio Abad-Vidal

1001 A estátua-menir do Pedrão ou de São Bartolomeu do Mar (Esposende, noroeste de Portugal) no contexto arqueológico da fachada costeira de entre os rios Neiva e Cávado Ana M. S. Bettencourt / Manuel Santos-Estévez / Pedro Pimenta Simões / Luís Gonçalves

1015 O Castro do Muro (Vandoma/Baltar, Paredes) - notas para uma biografia de ocupação da Idade do Bronze à Idade Média

Maria Antónia D. Silva / Ana M. S. Bettencourt / António Manuel S. P. Silva / Natália Félix

1031 Do Bronze Final à Idade Média - continuidades e hiatos na ocupação de Povoados em Oliveira de Azeméis João Tiago Tavares / Adriaan de Man

1041 As faunas do final da Idade do Bronze no Sul de Portugal: leituras desde o Outeiro do Circo (Beja)

Nelson J. Almeida / Íris Dias / Cleia Detry / Eduardo Porfírio / Miguel Serra

1055 A Espada do Monte das Oliveiras (Serpa) - uma arma do Bronze Pleno do Sudoeste Rui M. G. Monge Soares / Pedro Valério / Mariana Nabais / António M. Monge Soares

1065 São Julião da Branca (Albergaria-a-Velha) - Investigação e valorização de um povoado do Bronze Final

António Manuel S. P. Silva / Paulo A. P. Lemos / Sara Almeida e Silva / Edite Martins de Sá

1083 Do castro de S. João ao Mosteiro de Santa Clara: notícia de uma intervenção arqueológica, em Vila do Conde Rui Pinheiro 
1095 O castro de Ovil (Espinho), um quarto de século de investigação - resultados e questões em aberto

Jorge Fernando Salvador / António Manuel S. P. Silva

1111 O Castro de Salreu (Estarreja), um povoado proto-histórico no litoral do Entre Douro e Vouga

Sara Almeida e Silva / António Manuel S. P. Silva / Paulo A. P. Lemos / Edite Martins de Sá

1127 Castro de Nossa Senhora das Necessidades (Sernancelhe): uma primeira análise artefactual Telma Susana O. Ribeiro

${ }_{1141}$ A cividade de Bagunte. O estado atual da investigação Pedro Brochado de Almeida

1153 Zoomorfos na cerâmica da Idade do Ferro no NW Peninsular: inventário, cronologias e significado Nuno Oliveira / Cristina Seoane

1163 Vasos gregos em Portugal: diferentes maneiras de contar a história do intercâmbio cultural na Idade do Ferro

Daniela Ferreira

1175 Os exotica da necrópole da Idade do Ferro do Olival do Senhor dos Mártires (Alcácer do Sal) no seu contexto regional

Francisco B. Gomes

\section{Antiguidade Clássica e Tardia}

1191 O uso de madeira como combustível no sítio da Quinta de Crestelos (Baixo Sabor): da Idade do Ferro à Romanização Filipe Vaz / João Tereso / Sérgio Simões Pereira / José Sastre / Javier Larrazabal Galarza / Susana Cosme / José António Pereira / Israel Espi

1207 Cultivos de Época Romana no Baixo Sabor: continuidade em tempos de mudança? João Pedro Tereso / Sérgio Simões Pereira / Filipe Santos / Luís Seabra / Filipe Vaz

1221 A casa romana na Hispânia: aplicação dos modelos itálicos nas províncias ibéricas Fernanda Magalhães / Diego Machado / Manuela Martins

1235 As pinturas murais romanas da Rua General Sousa Machado, n. ${ }^{5}$ 1, Chaves José Carvalho

1243 Trás do Castelo (Vale de Mir, Pegarinhos, Alijó) - Uma exploração agrícola romana do Douro

Tony Silvino / Pedro Pereira

1255 A sequência de ocupação no quadrante sudeste de Bracara Augusta: as transformações de uma unidade doméstica Lara Fernandes / Manuela Martins

1263 Os Mosaicos com decoração geométrica e geométrico-vegetalista dos sítios arqueológicos da área do Conuentus Bracaraugustanus. Novas abordagens quanto à conservação, restauro, decoração e datação Maria de Fátima Abraços / Licínia Wrench

1277 “Casa Romana” do Castro de São Domingos (Cristelos, Lousada): Escavação, Estudo e Musealização Paulo André de P. Lemos

1291 A arqueobotânica no Castro de Guifões (Matosinhos, Noroeste de Portugal): O primeiro estudo carpológico

Luís Seabra / Andreia Arezes / Catarina Magalhães / José Varela / João Pedro Tereso 
1305 Um Horreum Augustano na Foz do Douro (Monte do Castelo de Gaia, Vila Nova de Gaia) Rui Ramos

1311 Ponderais romanos na Lusitânia: padrões, formas, materiais e contextos de utilização Diego Barrios Rodríguez

1323 Um almofariz centro-itálico na foz do Mondego

Marco Penajoia

1335 Estruturas romanas de Carnide - Lisboa Luísa Batalha / Mário Monteiro / Guilherme Cardoso

1347 O contexto funerário do sector da "necrópole NO" da Rua das Portas de S. Antão (Lisboa): o espaço, os artefactos, os indivíduos e a sua interconectividade na interpretação do passado Sílvia Loja, José Carlos Quaresma, Nelson Cabaço, Marina Lourenço, Sílvia Casimiro, Rodrigo Banha da Silva, Francisca Alves-Cardoso

${ }_{1361}$ Povoamento em época Romana na Amadora - resultados de um projeto pluridisciplinar Gisela Encarnação / Vanessa Dias

1371 A Arquitectura Residencial em Mirobriga (Santiago do Cacém): contributo a partir de um estudo de caso Filipe Sousa / Catarina Felício

${ }_{1385}$ O fim do ciclo. Saneamento e gestão de resíduos nos edifícios termais de Mirobriga (Santiago do Cacém)

Catarina Felício / Filipe Sousa

1399 Balsa, Topografia e Urbanismo de uma Cidade Portuária Vítor Silva Dias / João Pedro Bernardes / Celso Candeias / Cristina Tété Garcia

1413 No Largo das Mouras Velhas em Faro (2017): novas evidências da necrópole norte de Ossonoba e da sua ocupação medieval Ricardo Costeira da Silva / Paulo Botelho / Fernando Santos / Liliana Nunes

1429 Instrumentos de pesca recuperados numa fábrica de salga em Ossonoba (Faro) Inês Rasteiro / Ricardo Costeira da Silva / Paulo Botelho

1439 A Necrópole Romana do Eirô, Duas Igrejas (Penafiel): intervenção arqueológica de 2016 Laura Sousa / Teresa Soeiro

1457 Ritual, descarte ou afetividade? A presença de Canis lupus familiaris na Necrópole Noroeste de Olisipo (Lisboa)

Beatriz Calapez Santos / Sofia Simões Pereira / Rodrigo Banha da Silva / Sílvia Casimiro / Cleia Detry / Francisca Alves Cardoso

1467 Dinâmicas económicas em Bracara na Antiguidade Tardia Diego Machado / Manuela Martins / Fernanda Magalhães / Natália Botica

1479 Cerâmicas e Vidros da Antiguidade Tardia do Edifício sob a Igreja do Bom Jesus (Vila Nova de Gaia) Joaquim Filipe Ramos

1493 Novos contributos para a topografia histórica de Mértola no período romano e na Antiguidade Tardia Virgílio Lopes

\section{8. Época Medieval}

1511 Cerâmicas islâmicas no Garb setentrional "português": algumas evidências e incógnitas Constança dos Santos / Helena Catarino / Susana Gómez / Maria José Gonçalves / Isabel Inácio / Gonçalo Lopes / Jacinta Bugalhão / Sandra Cavaco / Jaquelina Covaneiro / Isabel Cristina Fernandes / Ana Sofia Gomes 
1525 Contributo para o conhecimento da cosmética islâmica, em Silves, durante a Idade Média Rosa Varela Gomes

1537 Yábura e o seu território - uma análise histórico-arqueológica de Évora entre os séculos VIII-XII José Rui Santos

1547 A encosta sul do Castelo de Palmela - resultados preliminares da escavação arqueológica Luís Filipe Pereira / Michelle Teixeira Santos

1559 A igreja de São Lourenço (Mouraria, Lisboa): um conjunto de silos e de cerâmica medieval islâmica

Andreia Filipa Moreira Rodrigues

1571 O registo material de movimentações populacionais no Médio Tejo, durante os séculos XII-XIII. Dois casos de "sunken featured buildings", nos concelhos de Cartaxo e Torres Novas Marco Liberato / Helena Santos / Nuno Santos

1585 O nordeste transmontano nos alvores da Idade média. Notas para reflexão Ana Maria da Costa Oliveira

1601 Sepulturas escavadas na rocha do Norte de Portugal e do Vale do Douro: primeiros resultados do Projecto SER-NPVD

Mário Jorge Barroca / César Guedes / Andreia Arezes / Ana Maria Oliveira

1619 "Portucalem Castrum Novum" entre o Mediterrâneo e o Atlântico: o estudo dos materiais cerâmicos alto-medievais do arqueossítio da rua de D. Hugo, nํ. 5 (Porto) João Luís Veloso

1627 A Alta Idade Média na fronteira de Lafões: notas preliminares sobre a Arqueologia no Concelho de Vouzela

Manuel Luís Real / Catarina Tente

1641 Um conjunto cerâmico medieval fora de portas: um breve testemunho aveirense Susana Temudo

${ }_{1651}$ Os Lóios do Porto: uma perspetiva integrada no panorama funerário da Baixa Idade Média à Época Moderna em meios urbanos em Portugal

Ana Lema Seabra

1659 O Caminho Português Interior de Santiago como eixo viário na Idade Média Pedro Azevedo

1665 Morfologia Urbana: Um exercício em torno do Castelo de Ourém André Donas-Botto / Jaqueline Pereira

1677 Intervenção arqueológica na Rua Marquês de Pombal/Largo do Espírito Santo (Bucelas, Loures)

Florbela Estêvão / Nathalie Antunes-Ferreira / Dário Ramos Neves / Inês Lisboa

1691 O Cemitério Medieval do Poço do Borratém e a espacialidade funerária na cidade de Lisboa Inês Belém / Vanessa Filipe / Vasco Noronha Vieira / Sónia Ferro / Rodrigo Banha da Silva

1705 Um Espaço Funerário Conventual do séc. XV em Lisboa: o caso do Convento de São Domingos da Cidade Sérgio Pedroso / Sílvia Casimiro / Rodrigo Banha da Silva / Francisca Alves Cardoso

\section{9. Época Moderna e Contemporânea}

1721 Arqueologia Moderna em Portugal: algumas reflexões críticas em torno da quantificação de conjuntos cerâmicos e suas inferências históricas e antropológicas Rodrigo Banha da Silva / André Bargão / Sara da Cruz Ferreira

1733 Faianças de dois contextos entre os finais do século XVI e XVIII do Palácio dos Condes de Penafiel, Lisboa

Martim Lopes / Tomás Mesquita 
1747 Um perfil de consumo do século XVIII na foz do Tejo: O caso do Mercado da Ribeira, Lisboa Sara da Cruz Ferreira / Rodrigo Banha da Silva / André Bargão

1761 Os Cachimbos dos Séculos XVII e XVIII do Palácio Mesquitela e Convento dos Inglesinhos (Lisboa)

Inês Simão / Marina Pinto / João Pimenta / Sara da Cruz Ferreira / André Bargão / Rodrigo Banha da Silva

1775 "Tomar os fumos da erua que chamão em Portugal erua sancta». Estudo de Cachimbos provenientes da Rua do Terreiro do Trigo, Lisboa

Miguel Martins de Sousa / José Pedro Henriques / Vanessa Galiza Filipe

1787 Cachimbos de Barro Caulínitico da Sé da Cidade Velha (República de Cabo Verde)

Rodrigo Banha da Silva / João Pimenta / Clementino Amaro

1801 Algumas considerações sobre espólio não cerâmico recuperado no Largo de Jesus (Lisboa) Carlos Boavida

1815 Adereços de vidro, dos séculos XVI-XVIII, procedentes do antigo Convento de Santana de Lisboa (anéis, braceletes e contas)

Joana Gonçalves / Rosa Varela Gomes / Mário Varela Gomes

1837 Da ostentação, luxo e poder à simplicidade do uso quotidiano: arqueologia e simbologia de joias e adornos da Idade Moderna Portuguesa Jéssica Iglésias

1849 Os amuletos em Portugal - dos objetos às superstições: o coral vermelho Alexandra Vieira

1865 Cerâmicas de Vila Franca de Xira nos séculos XV e XVI Eva Pires

1879 «Não passa por teu o que me pertence». Marcas de individualização associadas a faianças do Convento de Nossa Senhora de Aracoeli, Alcácer do Sal Catarina Parreira / Íris Fragoso / Miguel Martins de Sousa

1891 Cerâmica de Leiria: alguns focos de produção

Jaqueline Pereira / André Donas-Botto

1901 Os Fornos na Rua da Biquinha, em Óbidos Hugo Silva / Filipe Oliveira

1909 A casa de Pêro Fernandes, contador dos contos de D. Manuel I: o sítio arqueológico da Silha do Alferes, Seixal (século XVI) Mariana Nunes Ferreira

1921 O Alto da Vigia (Sintra) e a vigilância e defesa da costa Alexandre Gonçalves / Sandra Santos

1937 O contexto da torre sineira da Igreja de Santa Maria de Loures Paulo Calaveira / Martim Lopes

1949 A Necrópole do Hospital Militar do Castelo de São Jorge e as práticas funerárias na Lisboa de Época Moderna Susana Henriques / Liliana Matias de Carvalho / Ana Amarante / Sofia N. Wasterlain

1963 SAND - Sarilhos Grandes Entre dois Mundos: o adro da Igreja e a Paleobiologia dos ossos humanos recuperados

Paula Alves Pereira / Roger Lee Jesus / Bruno M. Magalhães

1975 Expansão urbana da vila de Cascais no século XVII e XVIII: a intervenção arqueológica na Rua da Vitória no 15 a 17

Tiago Pereira / Vanessa Filipe

1987 Novos dados para o conhecimento do Urbanismo de Faro em época Moderna Ana Rosa 
1995 Um exemplo de Arqueologia Urbana em Alcoutim: o Antigo Edifício dos CTT Marco Fernandes / Marta Dias / Alexandra Gradim / Virgílio Lopes / Susana Gómez Martínez

2007 Palácio dos Ferrazes (Rua das Flores/Rua da Vitória, Porto): a cocheira de Domingos Oliveira Maia

Francisco Raimundo

2021 As muitas vidas de um edifício urbano: História, Arqueologia e Antropologia no antigo Recreatório Paroquial de Penafiel Helena Bernardo / Jorge Sampaio / Marta Borges

2035 O convento de Nossa Senhora da Esperança de Ponta Delgada: o contributo da arqueologia para o conhecimento de um monumento identitário João Gonçalves Araújo / N’Zinga Oliveira

2047 Arqueologia na ilha do Corvo... em busca da capela de Nossa Senhora do Rosário Tânia Manuel Casimiro / José Luís Neto / Luís Borges / Pedro Parreira

2059 Perdidos à vista da Costa. Trabalhos arqueológicos subaquáticos na Barra do Tejo Jorge Freire / José Bettencourt / Augusto Salgado

2071 Arqueologia marítima em Cabo Verde: enquadramento e primeiros resultados do projecto CONCHA

José Bettencourt / Adilson Dias / Carlos Lima / Christelle Chouzenoux / Cristóvão Fonseca / Dúnia Pereira / Gonçalo Lopes / Inês Coelho / Jaylson Monteiro / José Lima / Maria Eugénia Alves / Patrícia Carvalho / Tiago Silva

2085 Trabalhos arqueológicos na Cidade Velha (Ribeira Grande de Santiago, Cabo Verde): reflexões sobre um projecto de investigação e divulgação patrimonial André Teixeira / Jaylson Monteiro / Mariana Mateus / Nireide Tavares / Cristovão Fonseca / Gonçalo C. Lopes / Joana Bento Torres / Dúnia Pereira / André Bargão / Aurélie Mayer / Bruno Zélie / Carlos Lima / Christelle Chouzenoux / Inês Henriques / Inês Pinto Coelho / José Lima / Patrícia Carvalho / Tiago Silva

2103 A antiga fortificação de Quelba / Khor Kalba (E.A.U.). Resultados de quatro campanhas de escavações, problemáticas e perspectivas futuras Rui Carita / Rosa Varela Gomes / Mário Varela Gomes / Kamyar Kamyad

2123 Colónias para homens novos: arqueologia da colonização agrária fascista no noroeste ibérico Xurxo Ayán Vila / José Mạ . Señorán Martín 


\title{
OS EXOTICA DA NECRÓPOLE DA IDADE DO FERRO DO OLIVAL DO SENHOR DOS MÁRTIRES (ALCÁCER DO SAL) NO SEU CONTEXTO REGIONAL
}

\author{
Francisco B. Gomes ${ }^{1}$
}

\begin{abstract}
RESUMO
Ao largo da sua longa existência (meados do século VII a meados do II a.n.e.), a necrópole da Idade do Ferro do Olival do Senhor dos Mártires (Alcácer do Sal) manteve uma estreita afinidade cultural com o Sul peninsular e o Mediterrâneo, expressa, entre muitos outros aspectos, pela presença de um conjunto de exotica (vidro, cornalina, amuletos de tipo egípcio e púnico, marfim/osso e ovo de avestruz) plausivelmente correspondentes a importações mediterrâneas ou de tipo mediterrâneo. Na presente contribuição analisa-se a posição destes elementos na sequência da necrópole, contextualizando-os no repertório de elementos importados durante a Idade do Ferro regional.

Palavras-chave: Olival do Senhor dos Mártires (Alcácer do Sal), Idade do Ferro, Exotica, Comércio mediterrâneo, Consumo.
\end{abstract}

\begin{abstract}

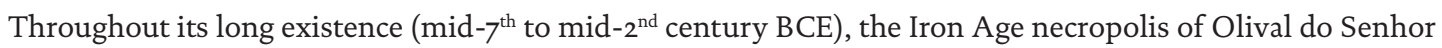
dos Mártires (Alcácer do Sal) shows a close cultural affinity with the southern Iberian Peninsula and the Mediterranean, which can be gauged, among many other aspects, by the presence of a small assemblage of exotica (glass, carnelian, Egyptian and Punic type amulets, ivory/bone and ostrich egg shell) which likely correspond to Mediterranean or Mediterranean-type imports. In this contribution these elements are set against the backdrop of the necropolis's sequence and analysed in light of the repertoire of imported elements known for the regional Iron Age.

Keywords: Olival do Senhor dos Mártires (Alcácer do Sal), Iron Age, Exotica, Mediterranean trade, Consumption.
\end{abstract}

\section{O ENQUADRAMENTO: A SEQUÊNCIA DE UTILIZAÇÃO DA NECRÓPOLE DO OLIVAL DO SENHOR DOS MÁRTIRES DURANTE A IDADE DO FERRO}

Conhecida desde finais do século XIX, a necrópole do Olival do Senhor dos Mártires (Alcácer do Sal) ${ }^{2}$ (Figura 1) constitui provavelmente o conjunto funerário da Idade do Ferro mais longa e intensamente estudado do Sul do actual território português. A complexa história da investigação sobre o sítio, que pode aferir-se pela extensa bibliografia dedicada ao mesmo (para uma síntese, ver Gomes, 2016: 72-
80), foi já exposta em detalhe em várias ocasiões (Paixão, 1970: 25-42; Rouillard et al., 1988-1989: 46-50; Fabião, 1998: 350-351; Gomes, 2016: 72-80), não parecendo pertinente neste contexto repetir essa narrativa.

Pelo contrário, e como forma de contextualizar os materiais analisados na presente contribuição, parece imprescindível recordar, em traços gerais, a sequência de utilização do OSM como área funerária por excelência da comunidade instalada na área dos actuais castelo e centro histórico de Alcácer do Sal (Silva et al., 1980-1981; Gomes, 2008; Arruda, 2014: 520-524).

1. UNIARQ - Centro de Arqueologia da Universidade de Lisboa; Faculdade de Letras da Universidade de Lisboa; Fundação para a Ciência e Tecnologia - franciscojbgomes@gmail.com.

2. De aqui em diante abreviada como OSM. 
Apesar do carácter muitas vezes lacunar da informação disponível, os dados veiculados por Vergílio Correia (1972a [1925]; 1972b [1927]) e António Cavaleiro Paixão $(1970$; 1983) relativos aos conjuntos funerários por si identificados e escavados, somados ao estudo exaustivo dos materiais recolhidos na necrópole (Gomes, 2016), permitem hoje reconhecer a sua longa diacronia de uso, desde os inícios da Idade do Ferro regional em meados do século VII a.n.e. até ao período romano republicano, bem como estabelecer com alguma segurança o seu faseamento interno (idem).

Assim, o primeiro momento de utilização do OSM como espaço funerário corresponde, grosso modo, à I Idade do Ferro regional (meados do século VII - segundo quartel / meados do $\mathrm{V}$ a.n.e.); dentro desse período podem contudo distinguir-se duas etapas diferenciadas. Assim, entre c. 650 e 575/550 a.n.e., assiste-se a uma primeira etapa, caracterizada pela diversidade de soluções funerárias (cremações in situ em fossas de perfil escalonado e em busta simples convivendo com cremações com deposição secundária dos restos em urnas "Cruz del Negro") e pela presença de espólios funerários ricos e, nalguns casos, aparatosos (Gomes, 2016: 345-346).

No segundo quartel do século VI a.n.e. parece contudo verificar-se uma homogeneização das práticas funerárias. A cremação in situ em busta simples converte-se na solução funerária predominante, senão mesmo exclusiva, desaparecendo dos espólios documentados nas sepulturas alguns dos elementos de aparato mais destacados (Gomes, 2016: 346-347). Esta etapa poderia corresponder a uma fase de consolidação das instituições urbanas de *Beuipo/Alcácer do Sal, que roubariam protagonismo à arena funerária como palcos de representação do estatuto e do poder.

A segunda grande etapa de utilização do espaço funerário do OSM corresponde genericamente à II Idade do Ferro regional, que caberia balizar entre os meados do século $V$ a.n.e. e os meados ou o terceiro quartel do II a.n.e. (Gomes, 2016: 347-350; 2018a). Os momentos iniciais desta nova etapa (c. 450-40o a.n.e.) encontram-se ainda mal caracterizados, embora as evidências disponíveis sugiram que é neste período que se generalizam os enterramentos em urna, que apresentam características notavelmente alinhadas com os da Baixa Andaluzia e, até certo ponto, do Sudeste e do Levante ibérico (v. Gomes, 2018a, com bibliografia).

$\mathrm{O}$ apogeu desta segunda etapa parece contudo cor- responder já à primeira metade do século IV a.n.e., em que se documenta a presença de ricos conjuntos funerários (ibidem) integrando panóplias armamentárias complexas, elementos de indumentária destacados e um rico repertório cerâmico que engloba um significativo conjunto de vasos gregos (Rouillard et al., 1988-1989; Gomes, 2017).

Após a quebra no abastecimento da cerâmica grega, a escassez de bons fósseis-directores para o período que medeia entre os meados do século IV e os meados / terceiro quartel do II a.n.e. dificultou o reconhecimento das fases mais tardias da necrópole. Ainda assim, em trabalhos recentes foi possível reconhecer um conjunto de materiais que podem distribuir-se por esse intervalo cronológico (Gomes, 2018a: 128-130), confirmando a continuidade do uso deste espaço funerário.

Em todo o caso, parece importante recordar que ao longo de toda esta plurissecular sequência de utilização, tanto os rituais e arquitecturas funerárias como a própria cultura material exumada no OSM revelam uma contínua afinidade cultural com o Sul peninsular e, através deste, com o Mediterrâneo.

Com efeito, numa primeira etapa, as pautas culturais documentadas nesta necrópole parecem estreitamente alinhadas com as do mundo "orientalizante" do Sudoeste peninsular, revelando por outro lado a influência da presença colonial fenícia no Baixo Sado (Arruda, 1999-2000: 63-100; Mayet \& Silva, 2000; Silva, 2005). Numa segunda etapa, e contrariamente ao defendido por alguns autores (Beirão, Gomes \& Monteiro, 1979), a necrópole do OSM revela a continuidade das estreitas relações da comunidade local com a Baixa Andaluzia "turdetana”, bem como o estabelecimento de novos laços com a área "ibérica" do Sudeste e do Levante (v. Gomes, 2018a). Os aspectos da cultura material móvel e imóvel do OSM que denunciam essa afinidade preferencial com a área meridional e com o Mediterrâneo são numerosos e diversos (v. Gomes, 2016; 2018a). Entre eles, destaca-se contudo a presença de um pequeno mas expressivo conjunto de elementos que, pela sua natureza, devem em princípio considerar-se como importações mediterrâneas ou, pelo menos, de tipo mediterrâneo.

Além de um certo número de recipientes cerâmicos, já estudados (v. Gomes, 2016, com bibliografia), esse conjunto engloba diversos elementos de adorno e/ou apotropaicos em matérias-primas exóticas que, apesar de em muitos casos terem já sido estu- 
dados de forma isolada (v. infra), não foram ainda objecto de uma apreciação de conjunto. O presente contributo pretende precisamente valorizar estes últimos elementos, analisando a sua distribuição ao longo da sequência da necrópole do OSM e contextualizando-os no panorama regional actualmente conhecido.

\section{OS EXOTICA DA NECRÓPOLE DE ALCÁCER DO SAL}

\subsection{O vidro e a faiança}

O vidro ocupa um lugar destacado no inventário dos elementos importados mediterrâneos, ou de tipo mediterrâneo, da Idade do Ferro do Sudoeste peninsular. Os elementos de colar produzidos nesta matéria-prima são com efeito uma presença habitual nos contextos deste período, particularmente durante os séculos VI e V a.n.e..

Em face deste panorama, e especialmente da profusão de elementos vítreos noutros conjuntos funerários sidéricos do território meridional português, o conjunto de elementos de adorno de vidro do OSM surpreende pela sua pequena dimensão. Com efeito, entre o extenso conjunto de materiais recolhidos no sítio contabilizam-se apenas três contas de colar de vidro (Figura 2, nn. 1-3).

Todas estas contas correspondem a peças de morfologia esférica achatada de matriz azul turquesa com decorações oculadas estratificadas a branco e azul ultramarino. Em duas delas as oculações são simples, distribuindo-se ao longo do eixo transversal da peça; o terceiro exemplar, em contrapartida, apresenta oculações simples alternadas com oculações geminadas, formando um padrão decorativo invulgar neste tipo de contas. Estas peças apresentam dimensões homogéneas, com diâmetros de $1 \mathrm{~cm}$ e alturas entre 0,65 e $0,8 \mathrm{~cm}$.

As contas deste tipo são presença habitual na maioria dos conjuntos da Idade do Ferro do Sudoeste peninsular. Assim, e num entorno regional alargado, caberia mencionar a presença de contas similares às do OSM nas necrópoles da Herdade do Gaio (Sines) (Costa, 1967; 1972), do Galeado (Vila Nova de Milfontes) (Beirão \& Gomes, 1983: 226; Fig. 16), da Nora Velha (Aljustrel) (Soares \& Martins, 2013: Fig. 5), da Mealha Nova (Ourique) (Dias, Beirão \& Coelho, 1970: 219) e da Fonte Santa (Ourique) (Beirão, 1986; 71-74), bem como, possivelmente, no conjunto funerário de Corte Margarida (Aljustrel)
(Deus \& Correia, 2005). Em contextos não funerários haveria a assinalar os exemplares do povoado de Fernão Vaz (Ourique) (Beirão \& Gomes, 1986: Fig. 2), do santuário de Corvo I (Castro Verde) (Maia \& Maia, 1986) e do povoado das Mesas do Castelinho (Almodôvar) (Estrela, 2019: 205-206).

Mais a Norte, as contas deste tipo estão documentadas nos conjuntos das necrópoles da Vinha das Caliças 4 (Beja) (Arruda et al., 2017: Fig. 18), do Monte do Bolor 1-2 (Beja) (Soares et al., 2017: 284-285) e talvez também de Palhais (Beja) (Santos et al., 2017: 238), bem como, já no Alentejo Central, na necrópole da Tera (Mora) (Mataloto, 2010-2011: 92) e, no Alto Alentejo, no povoado da Cabeça de Vaiamonte (Monforte) (Fabião, 2001: 204).

Quanto ao território algarvio, podem identificar-se contas muito similares às que aqui nos ocupam na necrópole da Fonte Velha de Bensafrim (Lagos) (Veiga, 2005 [1891]: Est. XXVIII), na da Hortinha (Lagos) ${ }^{3}$ e na de Cômoros da Portela (Veiga, 2005 [1891]: 259; Est. XXVIII, n. 8).

Já no âmbito da Estremadura e do Baixo Tejo estão documentadas contas similares na gruta-santuário da Lapa da Cova (Sesimbra) (Calado et al., 2017: 535536; Fig. 3) e no povoado da Quinta do Almaraz (Almada) (Filardi, 2011: Fig. 1.6.1), bem como em Freiria (Cascais), no Moinho da Atalaia (Amadora), no Porto do Sabugueiro (Salvaterra de Magos), na Alcáçova de Santarém e no sítio de Moinhos Velhos (Torres Vedras) (Arruda et al., 2016, com bibliografia). Poderiam ainda citar-se muitos outros paralelos mais distantes, reveladores da origem mediterrânea deste tipo de peças (Ruano Ruiz 200o: 63-64; 111-112). Como se podeapreciar pelos paralelos anteriormente enunciados, este tipo de contas é relativamente corrente no Sudoeste, mas também no âmbito mediterrâneo, com destaque para as áreas mais directamente tocadas pela influência fenícia e púnica. Devido à sua transversalidade, torna-se difícil situar estes elementos de colar, infelizmente sem contexto preciso, na sequência da necrópole. Ainda assim, a ponderação da cronologia dos paralelos disponíveis, somada ao que actualmente conhecemos sobre os ritmos de importação e consumo das contas de vidro, permite sugerir que as três peças do OSM procederão de sepulturas enquadráveis nos séculos VI e V a.n.e., podendo talvez integrar-se na segunda etapa da I Idade do Ferro anteriormente comentada.

3. Materiais em depósito no MNA, actualmente em estudo. 
Uma outra conta, anteriormente identificada como de vidro, parece na realidade corresponder a um exemplar de faiança, esférico, de tonalidade azul esverdeada e dotado de ranhuras longitudinais irregulares que lhe conferem um aspecto galonado (Figura 2, n. 4). Corresponde a uma peça de pequenas dimensões, com um diâmetro de $1,4 \mathrm{~cm}$ e uma altura de $1,25 \mathrm{~cm}$.

Ao contrário das contas galonadas de vidro, relativamente bem conhecidas no Sul de Portugal (Fabião, 2001: 203; Filardi, 2011: Fig. 1.6.1; Arruda et al., 2016: Fig. 5; Estrela, 2019: 204; v. tb. Ruano Ruiz 2000: 124), as contas de faiança deste tipo estão escassamente documentadas na região, excepção feita aos exemplares do possível enterramento da II Idade do Ferro de Fronteira (Vila do Bispo) (Viana, Formosinho \& Ferreira, 1953: 12 e Lám. I, n. 13). Tal facto poderá dever-se ao facto de as contas deste material não terem sido devidamente individualizadas regionalmente até datas relativamente recentes, graças sobretudo ao achado de grandes quantidades de exemplares discoides nas necrópoles da área de Beja (Santos et al. 2017: Fig. 7; Arruda et al. 2017: 212). Em face da presença de elementos deste tipo noutros contextos (Viana, Formosinho \& Ferreira, 1953: $12 \mathrm{e}$ Lám. I, n. 13; v. tb. Verdú Parra 2015: Fig. 3.447), caberia esperar que no futuro se venham a identificar novos exemplos que permitam definir melhor a cronologia da peça do OSM, que de momento caberia situar genericamente na II Idade do Ferro.

A estes escassos elementos de adorno haveria a acrescentar um fragmento de vidro polícromo (Figura 2, n. 5), ostentando uma matriz azul ultramarina e uma decoração de linhas paralelas (possivelmente em espiral) amarelas e brancas. Apresenta ainda um pequeno elemento cilíndrico, azul de cádmio, aplicado sobre a superfície, possivelmente correspondente aos restos deformados de uma pequena asa.

Apesar das suas pequenas dimensões e do seu mau estado de conservação, resultado da sua exposição ao fogo, este fragmento pertencerá muito provavelmente a um recipiente moldado sobre núcleo friável, cuja tipologia infelizmente não é possível precisar. Ainda assim, o esquema cromático e decorativo que se entrevê no fragmento preservado permite pensar que a peça em apreço se integraria no chamado Grupo Mediterrâneo I (Harden, 1981: 59-93; Grose, 1989: 110-115).

Quanto ao seu contexto, a informação patente no inventário do Museu Nacional de Arqueologia indi- ca que esta peça procede da Sepultura 6 de Vergílio Correia, contexto que contudo oferece significativos problemas de leitura, na medida em que se atribuem ao mesmo materiais com cronologias algo discrepantes (Gomes, 2016: Anexo III). Ainda assim, os materiais que lhe são atribuídos distribuem-se por um intervalo entre o século VI e o IV a.n.e., consistente com a atribuição do recipiente em análise ao Grupo Mediterrâneo 1.

Com efeito, estes recipientes, de provável produção grega,parecemter-seproduzidoedifundidopeloMediterrâneo entre os meados do século VI e os inícios do IV a.n.e. (Harden, 1981: 58; Grose, 1989: 110-111). Menos comuns do que as contas de vidro, os recipientes deste grupo estão também bem documentados no Extremo Ocidente peninsular (Feugère, 1989; Jiménez Ávila, 1999: Mapa 1; 2003: Fig. 4; Fabião, 2001: Fig. 14). Parece ocioso repetir, neste contexto, o panorama já esboçado nas várias sínteses disponíveis, embora deva chamar-se a atenção para a presença de um outro fragmento de vidro polícromo atribuível a um recipiente deste grupo procedente do povoado de Alcácer do Sal, concretamente dos contextos do século $\mathrm{V}$ a.n.e. documentados na área do Castelo (Silva et al., 1980-1981: Fig. 18, n. 224).

Podem por outro lado citar-se os achados mais recentes da Malhada das Taliscas (Alandroal) (Calado, Mataloto \& Rocha, 2007: 156), do Monte da Tera (Mataloto, 2010-2011: Fig. 8) ou, já na Estremadura/ Baixo Tejo, os de Castelo dos Mouros (Sintra) (Silva \& Sousa, 2016) e de Cabeço Guião (Arruda et al., 2017: Fig. 29) ${ }^{4}$, que vieram incrementar a densidade da malha de dispersão deste tipo de recipientes anteriormente conhecida (Jiménez Ávila, 1999: Mapa 1; 2003: Fig. 4; Fabião, 2001: Fig. 14). A estes achados vem agora somar-se o exemplar do OSM, reforçando o peso destes pequenos contentores de perfumes ou unguentos nas economias de prestígio regionais do período em apreço.

\subsection{A cornalina}

Embora bastante menos frequente do que o vidro, a cornalina constitui também uma presença relativamente frequente no repertório dos elementos de adorno da Idade do Ferro (cf. Gomes 2018b).

\footnotetext{
4. A integração deste último exemplar no Grupo Mediterrâneo 1 não é segura, podendo também pertencer já ao Grupo Mediterrâneo 2, mais raro - mas não desconhecido - no Extremo Ocidente peninsular.
} 
No OSM, contudo, esta matéria-prima de origem exótica, muito provavelmente egípcia (Martín de la Cruz, 2004; Martín de la Cruz et al., 2005; Gomes, 2018b), encontra-se possivelmente representada por uma única conta de colar (Figura 2, n. 6), de morfologia esférica, com 1,1 cm de diâmetro e 1,1cm de altura. A identificação da matéria-prima desta conta levanta contudo certas reservas, não podendo excluir-se igualmente que corresponda a um elemento de âmbar.

Em todo o caso, caberia recordar que no panorama actualmente conhecido as contas de cornalina esféricas são menos comuns do que as bitroncocónicas (Gomes, 2018b: 63-64); ainda assim, e no âmbito regional mais próximo, caberia citar a presença de contas desta morfologia no depósito votivo de Garvão (Ourique) (Beirão et al., 1985: 92 e Fig. 35, nn. 99-101), pertencentes portanto a uma cronologia tardia, do final do século III ou mesmo dos inícios do II a.n.e.. No entanto, nos contextos fenícios e púnicos do Levante e do Sul peninsular não faltam exemplares de contas de cornalina esféricas mais antigas, distribuídas entre os finais do século VIII/ inícios do VII e o século IV a.n.e. (Gomes 2018b: 64, com bibliografia).

Infelizmente, a peça do OSM não dispõe de coordenadas contextuais, pelo que, dada a larga diacronia abarcada pelos paralelos disponíveis, não parece possível determinar a que momento concreto dentro da sequência da necrópole pertence. Ainda assim, caberia notar que o período de máxima difusão dos adornos de cornalina no Sul de Portugal corresponde aos séculos VI e V a.n.e., podendo como hipótese pensar-se que a conta do OSM se enquadrará também nesse horizonte cronológico.

\subsection{Os aegyptiaca}

Entre os exotica recolhidos durante as intervenções realizadas no OSM, os escaravelhos de tipo egípcio foram sem dúvida os que mereceram maior atenção, tendo sido publicados pelos seus descobridores (Correia, 1972C [1925]; Paixão, 1971; 1983; Gamer-Wallert \& Paixão, 1983) e posteriormente analisados em diversos trabalhos de síntese, quer sobre os aegyptiaca peninsulares (Gamer-Wallert, 1978: 104-107; García Martínez, 2001: 169-175), quer especificamente sobre os escaravelhos e escarabóides do Sul de Portugal (Almagro-Gorbea \& Torres Ortiz, 2009: 528-534).

Os cinco escaravelhos de tipo egípcio do OSM (Fi- gura 2, nn. 7-11) foram objecto de análise muito aprofundada em data recente por parte de Martín Almagro-Gorbea e Mariano Torres Ortiz (2009: 528-534), pelo que parece redundante insistir neste contexto nas suas características específicas, que se sintetizam no quadro da Figura 3. Deve, no entanto, recordar-se que os exemplares alcacerenses se integram num panorama mais vasto. Com efeito, os escaravelhos e escarabóides egípcios e/ou de tipo egípcio constituem uma ocorrência relativamente frequente no Sul do actual território nacional, particularmente em contextos funerários, podendo citar-se, além dos exemplares já resenhados pelos autores citados (idem), os achados mais recentes da Vinha das Caliças 4 (Arruda et al., 2017), do Monte do Bolor 1-2 (Soares et al., 2017) e de Palhais (Santos et al., 2017), que vieram enriquecer de forma significativa o repertório regional deste tipo de elementos.

Atéao momento, os exemplares do OSM encontram-se relativamente isolados no seu âmbito regional mais próximo, o do Baixo Sado, marcando contudo uma das possíveis rotas de difusão deste tipo de elementos para o interior alentejano, onde são comparativamente abundantes. Não deve no entanto esquecer-se que os aegyptiaca estão igualmente representados no povoado de Alcácer do Sal, concretamente por uma placa-amuleto de faiança procedente da área do Convento de Aracoeli (Gomes, 2008: 21), pertencente ao conhecido tipo vaca/udjat (López Grande \& Velázquez Brieva, 2011-2012), que confirma o papel de centro de consumo e, eventualmente, de redistribuição de aegyptiaca do polo sadino.

\subsection{Os amuletos "púnicos"}

Aparte dos objectos apotropaicos de tipo egípcio anteriormente comentados, na necrópole do OSM recolheram-se também três outras peças que poderiam enquadrar-se no vasto universo dos chamados amuletos "púnicos". Estas três peças, de faiança de tonalidade azul esverdeada, foram recentemente estudadas com alguma profundidade (Gomes, no prelo; v. tb. Gomes, 2016: 318-320), pelo que neste contexto se oferecerá apenas um resumo das suas características principais.

O primeiro e mais representativo destes amuletos corresponde a uma figuração itifálica do deus Bes (Figura 4, n. 12), de pequenas dimensões ( $3 \mathrm{~cm}$ de comprimento por $1,7 \mathrm{~cm}$ de largura). Os amuletos figurando esta divindade de origem egípcia são muito comuns no Mediterrâneo púnico, alcançando o Me- 
diterrâneo Ocidental e a Península Ibérica (Gómez Peña \& Rodríguez Mellado, 2014: Tabla 1).

Infelizmente, desconhece-se actualmente o contexto exacto em que se recolheu o amuleto do OSM, não sendo por isso possível situá-lo com segurança na sequência de uso da necrópole. Ainda assim, deve assinalar-se que a documentação peninsular, recentemente compilada (Gómez Peña \& Rodríguez Mellado, 2014), parece sugerir que a maioria dos amuletos com figurações de Bes do Ocidente se concentram num período centrado entre os séculos VI e o V/IV a.n.e. (idem: 109-111), cronologia que os exemplares de Ibiza não desmentem (López-Grande et al., 2014: 169-170).

O segundo amuleto "púnico" do OSM (Figura 4, n. 13) oferece maiores dificuldades do ponto de vista da sua interpretação iconográfica. A priori, esta peça, com $2,3 \mathrm{~cm}$ de comprimento e $0,3 \mathrm{~cm}$ de largura máxima, poderia interpretar-se como um amuleto fálico (Gomes, 2016: 319), embora alguns detalhes, como as estrias longitudinais, pareçam algo deslocadas numa figuração dessa natureza. Por outro lado, peças similares (mas desprovidas de sulcos) procedentes de contextos púnicos da Sardenha foram interpretados como representações de seios (Acquaro, 1977: nn. 22-23), leitura que tão-pouco se adequa de forma clara ao exemplar alcacerense.

Independentemente destas dúvidas quanto à sua interpretação iconográfica, caberia salientar que os paralelos exactos para este amuleto são raros. Pode contudo recordar-se que Horace Beck, no seu clássico estudo sobre as contas de colar, classifica este tipo de objectos no seu Grupo XXIII, e concretamente no Tipo B.3.a, ilustrado por um exemplar egípcio da Baixa Época (Beck, 1928: Fig. 21). No âmbito peninsular parece documentar-se um único exemplar análogo ao do OSM, procedente da necrópole de La Albufereta (Alicante), infelizmente sem contexto seguro (Verdú Parra, 2015: 398 y Fig. 3447). A peça alicantina não será contudo anterior ao século $\mathrm{V}$ a.n.e., pelo que o exemplar do OSM, infelizmente também ele desprovido de coordenadas contextuais, poderá tentativamente atribuir-se ao horizonte da II Idade do Ferro da necrópole.

Finalmente, o terceiro amuleto recolhido no conjunto funerário sadino, também ele de pequenas dimensões (1,9cm de comprimento por $1 \mathrm{~cm}$ de largura), parece corresponder a uma representação realista dos genitais masculinos e da correspondente área púbica (Figura 4, n. 14). Este motivo encontra-se bem re- presentado nos amuletos egípcios, atribuindo-se as representações do mesmo em faiança já ao período Ptolemaico (Müller-Winckler, 1987: 193); no Mediterrâneo Central e Ocidental, pelo contrário, não se conhecem amuletos deste tipo realizados em faiança, ainda que o motivo seja frequente entre os amuletos púnicos de osso de Ibiza (Fernández et al., 2009: Tipo 4.1.1).

Em face do exposto, caberia pensar que, tal como o exemplar putativamente fálico antes descrito, este amuleto se terá depositado nalgum enterramento integrável nos horizontes mais tardios do OSM, sem que possa igualmente excluir-se que se trate de uma peça já de cronologia republicana.

\subsection{O marfim/osso}

A presença de marfim ou osso trabalhado no OSM é francamente vestigial, resumindo-se na prática a uma placa circular que ostenta decoração gravada numa das faces, concretamente a representação de uma roseta de 16 pétalas enquadrada por uma moldura formada por dois círculos concêntricos (Figura 4, n. 15) (Gomes, 2016: Est. CXLII, n.1166). Esta peça conta com um paralelo exacto entre os materiais do santuário ribeirinho da Rua do Rato, em Alcácer do Sal, datado do século VI a.n.e. (Arruda, 2014: Fig. 17). Na ausência de dados contextuais específicos, o exemplar do OSM deverá considerar-se contemporâneo desta outra placa procedente do povoado.

A esta peça poderia apenas acrescentar-se o uso do marfim/ osso como complemento decorativo de elementos metálicos, nomeadamente nos cabos de facas afalcatadas (Gomes, 2016: Est. LXVIII, nn. 765766; Est. LXIX, n. 773) e, num caso, como remate de uma dobradiça pertencente a um elemento de mobiliário, possivelmente uma banqueta funerária de tipo diphros (idem: Est. CXX, n. 1018). Os paralelos disponíveis para o tipo de objectos que serviu de suporte a estes elementos de eborária permite sugerir que os mesmos se concentrarão fundamentalmente no século VI a.n.e. (Gomes, 2016: 276 e 302-303).

\subsection{O ovo de avestruz}

A lista dos exotica do OSM aqui analisados encerra-se com um recipiente sobre ovo de avestruz (Figura 4, n. 16), infelizmente sem contexto preciso (Arruda, 2014: Figura 6; Gomes, 2016: 320-322). Esta peça integra-se na Forma II definida por María del Pilar San Nicolás para os recipientes de ovo de avestruz fenícios e púnicos peninsulares, corres- 
pondente a recipientes fechados obtidos mediante a extracção do quinto superior do ovo (San Nicolás 1975: 79). O bordo do recipiente assim obtido apresenta uma aresta contínua, o que permite aproximar o exemplar alcacerense da variante II-A definida por aquela mesma autora (idem: Lám. II). Quanto às suas dimensões, a peça do OSM apresenta um diâmetro máximo de $13,4 \mathrm{~cm}$, um diâmetro de bordo de $9 \mathrm{~cm}$ e uma altura total de $12,2 \mathrm{~cm}$.

Como é habitual nas peças da Forma II, a superfície do recipiente do OSM apresentar-se-ia decorada com motivos gravados e pintados, infelizmente hoje praticamente perdidos. Actualmente apenas se aprecia a presença de barras verticais que dividem o campo decorativo em métopas e de barras horizontais repartindo cada métopa em dois registos. O esquema composicional destas barras, de certa complexidade, não conta com paralelos exactos no repertório dos recipientes de ovo de avestruz peninsular, embora possa aproximar-se tentativamente dos Motivos $6 \mathrm{e}$ 8 de María del Pilar San Nicolás (1975: Lám. V).

Embora estejam muito bem representados no Mediterrâneo Ocidental (Savio 2004, com bibliografia), os recipientes de ovo de avestruz praticamente não alcançaram o actual território português, onde aparte do exemplar do OSM apenas haveria a citar os fragmentos exumados nas escavações do Palácio da Galeria, em Tavira (Maia, 2003: 68). No resto do Sudoeste peninsular o panorama não é muito mais rico, resumindo-se aos escassos exemplares de La Joya (Huelva), de El Carambolo (Camas) e das necrópole dos Alcores de Carmona (Cruz del Negro, El Acebuchal e Santa Lucía) (Savio, 2004: 71-72, com bibliografia).

Infelizmente, não dispomos de dados sobre o contexto original da peça em apreço, o que dificulta a correcta aferição da sua posição na sequência global da necrópole, sobretudo quando o mau estado de conservação da decoração impede qualquer comparação estilística aprofundada. Por outro lado, a produção e uso de recipientes de ovo de avestruz no âmbito fenício-púnico abarca uma longa diacronia, que se estende pelo menos do século VII ao século III ou mesmo ao II a.n.e., o que não ajuda a dilucidar a questão. Note-se no entanto que os poucos exemplares documentados no Sudoeste Peninsular procedem de contextos tendencialmente antigos, dos séculos VII e VI a.n.e., pelo que parece verosímil que o recipiente do OSM pertença também aos horizontes mais antigos da necrópole alcacerense.

\section{AS IMPORTAÇÕES MEDITERRÂNEAS DO OLIVAL DO SENHOR DOS MÁRTIRES NO SEU CONTEXTO REGIONAL}

Como se pode apreciar pelo panorama traçado nas páginas anteriores, os exotica do OSM, apesar de não muito numerosos, são diversificados e apresentam simultaneamente características que aproximam a necrópole sadina dos demais contextos funerários do Sul português e outros que a individualizam dentro do seu âmbito regional.

Desde logo, a presença de elementos de adorno de vidro e cornalina constitui um rasgo partilhado entre a necrópole sadina e muitas das suas congéneres alentejanas e algarvias. No entanto, em comparação com estas, o volume de materiais deste tipo no OSM parece algo surpreendente. Naturalmente esse facto pode dever-se a questões de conservação - a prática da cremação no OSM poderá ter obliterado muitos outros objectos, especialmente de vidro, que tenham originalmente existido -, mas também a factores culturais.

Com efeito, este tipo de elementos parece ser muito valorizado em contextos de povoamento eminentemente rural, sobretudo durante os séculos VI e V a.n.e., sendo contudo raros em ambientes de natureza (proto-)urbana, como bem demonstram os casos de Medellín (Almagro-Gorbea 2008a) ou de La Angorrilla (Alcalá del Río) (Fernández Flores et al. 2014), com os quais a comunidade de Alcácer do Sal pareceterpartilhadoum regimedevalordiferenciado do das comunidades rurais de outras áreas.

Quanto aos amuletos, destaca-se a riqueza do conjunto de escaravelhos de tipo egípcio, que bem poderia evidenciar o papel do pólo do Baixo Sado como centro redistribuidor, ajudando assim a compreender a abundante presença deste tipo de amuletos no interior alentejano. Pelo contrário, a presença dos amuletos de tipo "púnico" constitui uma especificidade do sítio sadino, que evidencia a sua proximidade com os núcleos de origem fenícia do Sul peninsular, com destaque naturalmente para Cádiz, onde este tipo de amuletos é também bem conhecido (cf. Perdigones, Muñóz \& Pisano 1990).

Quanto à eborária, o panorama do OSM é francamente modesto, faltando aqui por completo os produtos mais característicos da chamada eborária hispano-fenícia, tão frequentes nos ambientes funerários orientalizantes do vizinho território espanhol (Almagro-Gorbea 2008b, com bibliografia). Pelo 
contrário, a presença do recipiente de ovo de avestruz permite integrar o conjunto funerário alcacerense na lista restrita e exclusiva dos sítios do Sudoeste peninsular em que se identificaram elementos deste tipo (Savio 2004), destacando uma vez mais a estreita relação da comunidade alcacerense com o Sul peninsular e a sua capacidade de aceder às rotas comerciais que o conectavam com o Mediterrâneo.

Em face destas considerações, pode afirmar-se que o conjunto de exotica do OSM constitui simultaneamente um reflexo modesto mas fiel do repertório de importações mediterrâneas presentes na Idade do Ferro do Sul de Portugal, e, nalguns aspectos, uma excepção no quadro desse mesmo repertório, facto que reflecte a marcada personalidade própria do processo histórico da comunidade local, que nos últimos anos se tem vindo a evidenciar de forma cada vez mais clara (Gomes 2016; 2018).

\section{BIBLIOGRAFIA}

ACQUARO, Enrico (1977) - Amuleti egiziani ed egittizzanti del Museo nazionale di Cagliari. Roma: CNR.

ALMAGRO-GORBEA, Martín, dir. (2008a) - La necrópolis de Medellín. II. Estudios de los hallazgos. Madrid: Real Academia de la Historia.

ALMAGRO-GORBEA, Martín (2008b) - Objetos de marfil y hueso. In ALMAGRO-GORBEA, Martín, dir. - La necrópolis de Medellín. II. Estudios de los hallazgos. Madrid: Real Academia de la Historia, p. 401-512.

ALMAGRO-GORBEA, Martín; TORRES ORTIZ, Mariano (2009) - Los escarabeos fenicios de Portugal. Un estado de la cuestión. Estudos Arqueológicos de Oeiras. Oeiras. 17, pp. 521-554.

ARRUDA, Ana Margarida (1999-200o) - Los Fenicios en Portugal. Fenicios y mundo indígena en el centro y sur de Portugal (siglos VIII-VI a.C.). Barcelona: Universitat Pompeu Fabra.

ARRUDA, Ana Margarida (2014) - A Oeste tudo de novo. Novos dados e outros modelos interpretativos para a orientalização do território português. In ARRUDA, Ana Margarida, ed. - Fenícios e Púnicos, por Terra e Mar (2). Actas do VI Congresso Internacional de Estudos Fenícios e Púnicos. Lisboa: UNIARQ, p. 513-535.

ARRUDA, Ana Margarida; BARBOSA, Rui; GOMES, Francisco B.; SOUSA, Elisa de (2017) - A necrópole da Vinha das Caliças (Beja, Portugal). In JIMÉNEZ ÁVILA, Javier, ed. - Sidereum Ana III. El Río Guadiana y Tartessos. Mérida: Consorcio Ciudad de Mérida, p. 187-225.

ARRUDA, Ana Margarida; PEREIRA, Carlos; PIMENTA, João; SOUSA, Elisa de; MENDES, Henrique; SOARES, Rui
(2016) - As contas de vidro do Porto do Sabugueiro (Muge, Salvaterra de Magos, Portugal). CUPAUAM. Madrid. 42, pp. 79-101.

ARRUDA, Ana Margarida; SOUSA, Elisa de; BARRADAS, Elisabete; BATATA, Carlos; DETRY, Cleia; SOARES, Rui Monge (2017) - O Cabeço Guião (Cartaxo - Portugal): um sítio da Idade do Ferro do Vale do Tejo. In CELESTINO PÉREZ, Sebastián; RODRÍGUEZ GONZÁLEZ, Esther, eds. Territorios comparados: los valles del Guadalquivir, el Guadiana y el Tajo en época tartésica. Madrid: CSIC, p. 319-361.

BECK, Horace C. (1928) - Classification and nomenclature of beads and pendants. Archaeologia. Londres. 77, pp. 1-76.

BEIRÃO, Caetano de Mello (1986) - Une Civilisation Protohistorique du Sud du Portugal (Ier Âge du Fer). Paris: Éditions du Boccard.

BEIRÃO, Caetano de Mello; GOMES, Mário Varela (1983) - A necrópole da Idade do Ferro do Galeado (Vila Nova de Milfontes). O Arqueólogo Português. Lisboa. Série IV. 1, pp. 207-266.

BEIRÃO, Caetano de Mello; GOMES, Mário Varela (1986) - Grafitos da Idade do Ferro do Centro e Sul de Portugal. In de HOZ BRAZO, Javier, ed. - Actas del III Coloquio sobre Lenguas y Culturas Paleohispánicas. Salamanca: Universidad de Salamanca, p. 465-502.

BEIRÃO, Caetano de Mello; GOMES, Mário Varela; MONTEIRO, Jorge Pinho (1979) - As Estelas Epigrafadas da I Idade do Ferro do Sul de Portugal. Setúbal: MAEDS.

BEIRÃO, Caetano de Mello; SILVA, Carlos Tavares da; SOARES, Joaquina; GOMES, Mário Varela; GOMES, Rosa Varela (1985) - Depósito votivo da II Idade do Ferro de Garvão. Notícia da primeira campanha de escavações. O Arqueólogo Português. Série IV. 3, pp. 45-135.

CORREIA, Vergílio (1972a [1925]) - Uma conferência sobre a Necrópole de Alcácer do Sal. In Obras. Volume IV, Estudos Arqueológicos. Coimbra: Universidade de Coimbra, p. 151-168.

CORREIA, Vergílio (1972b [1928]) - Escavações realizadas

na Necrópole Pré-Romana de Alcácer do Sal em 1926 e 1927. In Obras. Volume IV, Estudos Arqueológicos. Coimbra: Universidade de Coimbra, p. 169-179.

CORREIA, Vergílio (1972c [1925]) - Um amuleto egípcio da Necrópole de Alcácer do Sal. In Obras. Volume IV, Estudos Arqueológicos. Coimbra: Universidade de Coimbra, p. 195-201.

CALADO, Manuel; GONÇALVES, Luís; MATALOTO, Rui; JIMÉNEZ ÁVILA, Javier (2017) - Lapa da Cova: un santuario costero en los acantilados de Sesimbra (Portugal). In MARTÍNEZ ALCALDE, María Martínez; GARCÍA CANO, José Miguel; BLÁNQUEZ PÉREZ, Juan; INIESTA SANMARTÍN, Ángel, eds. - Mazarrón II. Contexto, viabilidady perspectivas del barco B-2 de la bahía de Mazarrón. En homenaje a Julio Mas García. Madrid: Universidad Autónoma de Madrid: 525-545. 
CALADO, Manuel; MATALOTO, Rui; ROCHA, Artur (2007)-Povoamento Proto-Histórico na Margem Direita do Regolfo do Alqueva (Alentejo, Portugal). In RODRÍGUEZ DÍAZ, Alonso; PAVÓN SOLDEVILA, Ignacio, eds. - Arqueología de la Tierra. Paisajes rurales de la protohistoria peninsular. Cáceres: Universidad de Extremadura, p. 129-179.

COSTA, José Miguel da (1967) - O tesouro Fenício ou Cartaginês do Gaio (Sines). Ethnos. Lisboa. 5, pp. 529-537.

COSTA, José Miguel da (1972). O tesouro púnico-tartéssico do Gaio. In Actas das II Jornadas da Associação dos Arqueólogos Portugueses. Lisboa: Associação dos Arqueólogos Portugueses, p. 97-120

DEUS, Manuela de; CORREIA, José (2005) - Corte Margarida. Mais uma necrópole orientalizante no Baixo Alentejo. In CELESTINO PÉREZ, Sebastián; JIMÉNEZ ÁVILA, Javier, eds. - El Período Orientalizante. Madrid: CSIC, p. 615-618.

DIAS, Maria Manuela Alves; BEIRÃO, Caetano de Mello; COELHO, Luís (1971) - Duas necrópoles da Idade do Ferro no Baixo-Alentejo: Ourique. (Notícia preliminar). O Arqueólogo Português. Lisboa. Série III. 4, pp. 175-219.

ESTRELA, Susana (2019) - Adornos, espaço e tempo: as contas de colar em Mesas do Castelinho (Santa Clara-a-Nova, Almodôvar). Setúbal Arqueológica. Setúbal. 18, pp. 193-214.

FABIÃO, Carlos (1998) - O Mundo Indígena e a sua Romanização na Área Céltica do actual território português. Tese de Doutoramento. Universidade de Lisboa. Inédita.

FABIÃO, Carlos (2001) - Importações de origem mediterrânea no interior do sudoeste peninsular na segunda metade do I Milénio a.C.: materiais da Cabeça de Vaiamonte, Monforte. In Os Púnicos no Extremo Ocidente. Lisboa: FCSH-UNL, p. 197-228.

FERNÁNDEZ, Jordi H.; LÓPEZ-GRANDE, María José; MEZQUIDA, Ana; VELÁZQUEZ, Francisca (2009) - Amuletos púnicos de hueso hallados en Ibiza. Ibiza: Museo Arqueológico de Ibiza y Formentera.

FERNÁNDEZ FLORES, Álvaro; RODRÍGUEZ AZOGUE, Araceli; CASADO ARIZA, Manuel; PRADOS PÉREZ, Eduardo, coords. (2014) - La necrópolis de época tartésica de la Angorrilla (Alcalá del Río, Sevilla). Sevilha: Universidade de Sevilha.

FEUGÈRE, Michel (1989) - Les vases en verre sur noyau d'argile en Mediterranée nord-occidentale. In FEUGÈRE, Michel, ed. - Le verre préromain en Europe occidentale. Montpellier: Éditions Monique Mergoil, p. 29-62.

FILARDI, Vivian H (2011) - Caracterização química de contas de vidro arqueológicas do século VII a.C. provenientes da Quinta do Almaraz, Cacilhas. Tese de Mestrado. Universidade Nova de Lisboa. Inédita.

GAMER-WALLERT, Ingrid (1978) - Ägyptische und ägyptisierende Funde von der Iberischen Halbinsel. Wiesbaden: Reichert Verlag.
GAMER-WALLERT, Ingrid; PAIXÃO, António Cavaleiro (1983) - A inscrição do escaravelho de Psamético I, da necrópole do Olival do Senhor dos Mártires: novos elementos para a sua interpretação. O Arqueólogo Português. Lisboa. Série IV. 1, pp. 267-272.

GARCÍA MARTÍNEZ, María Antónia (2002) - Documentos prerromanos de tipo egipcio de la vertiente atlántica hispano-mauritana. Montpellier: Université Paul Valéry.

GOMES, Esmeralda (2008) - Os ex-votos proto-históricos do Castelo de Alcácer do Sal. Tese de Mestrado. Universidade de Lisboa. Inédita.

GOMES, Francisco B. (2014) - Importações mediterrâneas em contextos «Pós-Orientalizantes» do Sul de Portugal (séculos VI-IV a.n.e.). Onoba. Huelva. 2, pp. 27-44.

GOMES, Francisco B. (2016) - Contactos culturais e discursos identitários na I Idade do Ferro do Sul de Portugal (séculos VIII a V a.n.e.): leituras a partir do registo funerário. Tese de Doutoramento. Universidade de Lisboa. Inédita.

GOMES, Francisco B. (2017) - Un conjunto de cerámicas áticas inéditas de la necrópolis de Olival do Senhor dos Mártires (Alcácer do Sal, Portugal). Onoba. Huelva. 5, pp. 45-58.

GOMES, Francisco B. (2018a) - The Olival do Senhor dos Mártires necropolis (Alcácer do Sal, Portugal) during the Late Iron Age: new social, political and cultural insights. Zephyrus. Salamanca. LXXXI, pp. 117-139.

GOMES, Francisco B. (2018b) - La Cornalina en el Bronce Final y la Edad del Hierro del Sur de Portugal. Lucentum. Alicante. XXXVII, pp. 55-74.

GOMES, Francisco B. (no prelo) - Tres amuletos 'púnicos' inéditos de la necrópolis de Olival do Senhor dos Mártires (Alcácer do Sal, Portugal). In NIVEAU, Ana María, ed. Mare Sacrum. Religión, cultos y rituales fenicios en el Mediterráneo. Actas del X Coloquio Internacional del CEFYP. Cádiz: Universidad de Cádiz / CEFYP.

GÓMEZ PEÑA, Álvaro; RODRÍGUEZ MELLADO, Jesús (2014) - A propósito de dos nuevos amuletos de Bes procedentes de Chipiona y Rota (Cádiz). SPAL. Sevilha. 23, pp. 147-165.

GROSE, David F. (1989) - Early Ancient Glass. Toledo: Toledo Museum of Art.

HARDEN, Donald (1981) - Catalogue of Greek and Roman Glass in the British Museum. Volume 1, Core- and rodformed vessels and pendants and Mycenaean cast objects. Londres: British Museum.

LÓPEZ GRANDE, María José; VELÁZQUEZ BRIEVA, Francisca (2011-2012) - Amuletos-placa de iconografía egipcia: el modelo vaca/udjat en el ámbito fenicio-púnico. CuPAUAM. Madrid. 37-38, pp. 509-523.

LÓPEZ-GRANDE, María José; VELÁZQUEZ, Francisca; FERNÁNDEZ, Jordi H.; MEZQUIDA, Ana (2014) - Amu- 
letos de Iconografía Egipcia procedentes de Ibiza. Ibiza: Museo Arqueológico de Ibiza y Formentera.

MAIA, Maria; MAIA, Manuel (1986) - Arqueologia da área mineira de Neves Corvo. Trabalhos realizados no triénio 1982-84. Castro Verde: Somincor.

MARTÍN de la CRUZ, José Clemente (Coord.) (2004) Colgantes y cuentas de cornalina procedentes de Andalucía Occidental. Revista de Prehistoria. Córdova. 3, pp.7-47.

MARTÍN de la CRUZ, José Clemente; VERA RODRÍGUEZ, Juan Carlos; GAVILÁN CEVALLOS, Beatriz; PERLINES BENITO, María (2005) - Un colgante de cornalina de manufactura oriental procedente de la provincia de Córdoba. In CELESTINO PÉREZ, Sebastián; JIMÉNEZ ÁVILA, Javier (Eds.). El Período Orientalizante. Madrid: CSIC, p. 503-509.

MATALOTO, Rui (2010-2011) - Os Senhores da Terra: necrópoles e comunidades rurais do território alto alentejano nos sécs. VI-V aC. Arqueologia\&História. Lisboa. 62-63, pp. 77-100.

MÜLLER-WINKLER, Claudia (1987) - Die Ägyptischen Objekt-Amulette. Friburgo: Universidade de Friburgo.

PERDIGONES, Lorenzo; MUÑOZ, Ángel \& PISANO, Giovanna (1990). La necrópolis fenicio-púnica de Cádiz. Roma: Universitá degli Studi di Roma.

MAYET, Françoise \& SILVA, Carlos Tavares da (2000) L'établissement phénicien d'Abul. Portugal. Paris: Diffusion du Boccard.

PAIXÃO, António Cavaleiro (1970) - A necrópole do Senhor dos Mártires, Alcácer do Sal. Novos elementos para o seu estudo. Tese de Licenciatura. Universidade de Lisboa. Inédita.

PAIXÃO, António Cavaleiro (1971) - O recente achado de três escaravelhos na necrópole do Senhor dos Mártires em Alcácer do Sal. In: Actas do $11^{\circ}$ Congresso Nacional de Arqueologia. Coimbra: Universidade de Coimbra, p. 309-315.

PAIXÃO, António Cavaleiro (1983) - Uma nova sepultura com escaravelho da necrópole proto-histórica do Senhor dos Mártires, Alcácer do Sal. O Arqueólogo Português. Lisboa. Série IV. 1, pp. 273-286.

ROUILLARD, Pierre; PAIXÃO, António Cavaleiro; VILLANUEVA-PUIG, Marie-Christine; DURAND, Jean-Louis (1988-1989) - Les vases grecques d'Alcácer do Sal. O Arqueólogo Português. Lisboa. Série IV. 6-7, pp. 43-108.

RUANO RUIZ, Encarnación (200o) - Las cuentas de vidrio halladas en España desde la Edad del Bronce hasta el Mundo Romano. Madrid: Stock Cero.

SAN NICOLÁS, María del Pilar (1975) - Las cáscaras de huevo de avestruz fenicio-púnico en la Península Ibérica y Baleares. CuPAUAM. Madrid. 2, pp. 75-10o.
SANTOS, Filipe; ANTUNES, Ana Sofia; DEUS, Maria de; GRILO, Carolina (2017) - A necrópole de Palhais (Beringel, Beja). In JIMÉNEZ ÁVILA, Javier, ed. - Sidereum Ana III. El Río Guadiana y Tartessos. Mérida: Consórcio Ciudad de Mérida, p. 227-261.

SAVIO, Gigliola (2004) - Le uova di struzzo dipinte nella cultura punica. Madrid: Real Academia de la Historia.

SILVA, Carlos Tavares da (2005) - A presença fenícia e o processo de Orientalização nos Estuários do Tejo e do Sado. In: CELESTINO PÉREZ, Sebastián; JIMÉNEZ ÁVILA, Javier, eds. - El Período Orientalizante. Madrid: CSIC, p. 749-766.

SILVA, Carlos Tavares da; SOARES, Joaquina; BEIRÃO, Caetano de Mello; DIAS, Luísa Ferrer; COELHO-SOARES, Antónia (1980-1981) - Escavações arqueológicas no Castelo de Alcácer do Sal (campanha de 1979). Setúbal Arqueológica. Setúbal. 6-7, pp. 149-218.

SILVA, Rodrigo Banha da; SOUSA, Maria João (2016) - O Castelo dos Mouros nos Primeiros Séculos do I Milénio a.C.. Al-madan. Almada. 2O, pp. 22-26.

SOARES, Rui Monge; BAPTISTA, Lídia; PINHEIRO, Rui; OLIVEIRA, Lurdes; RODRIGUES, Zélia; VALE, Nélson (2017) - A necrópole da I Idade do Ferro do Monte do Bolor 1-2 (São Brissos, Beja). In JIMÉNEZ ÁVILA, Javier, ed. - Sidereum Ana III. El Río Guadiana y Tartessos. Mérida: Consorcio Ciudad de Mérida, p. 263-302.

SOARES, Rui Monge; MARTINS, A. (2013) - A necrópole da Nora Velha 2 (Ourique). Novos dados e interpretações 20 anos após a sua escavação. In ARNAUD, José Morais; MARTINS, Andrea; NEVES, César, coords., Arqueologia em Portugal. 150 Anos. Lisboa: Associação dos Arqueólogos Portugueses, p. 661-669.

VIANA, Abel; FORMOSINHO, J.; FERREIRA, Octávio da Veiga (1953) - De lo prerromano a lo arabe en el Museo Regional de Lagos. Archivo Español de Arqueología. Madrid. 26 , p. $113-138$.

VEIGA, Sebastião Estácio da (2005 [1891]) - Antiguidades Monumentaes do Algarve, Volume 4. Faro: Universidade do Algarve.

VERDÚ PARRA, Enric (2015) - La Necrópolis Ibérica de L'Albufereta (Alacant). Ritos y usos funerarios en un contexto de interacción cultural. Alicante: MARQ. 


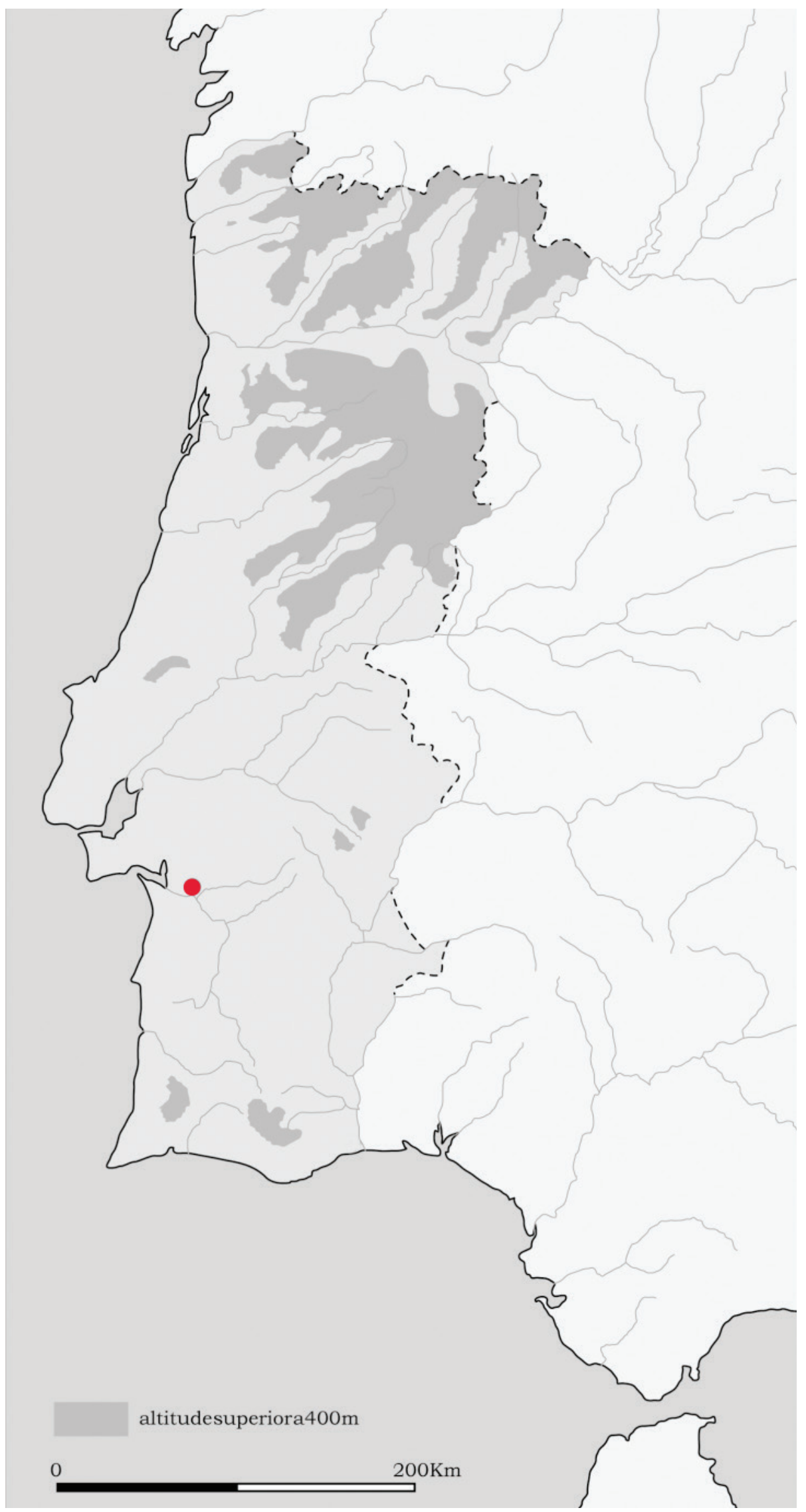

Figura 1 - Localização da necrópole do Olival do Senhor dos Mártires (base cartográfica: Victor S. Gonçalves). 


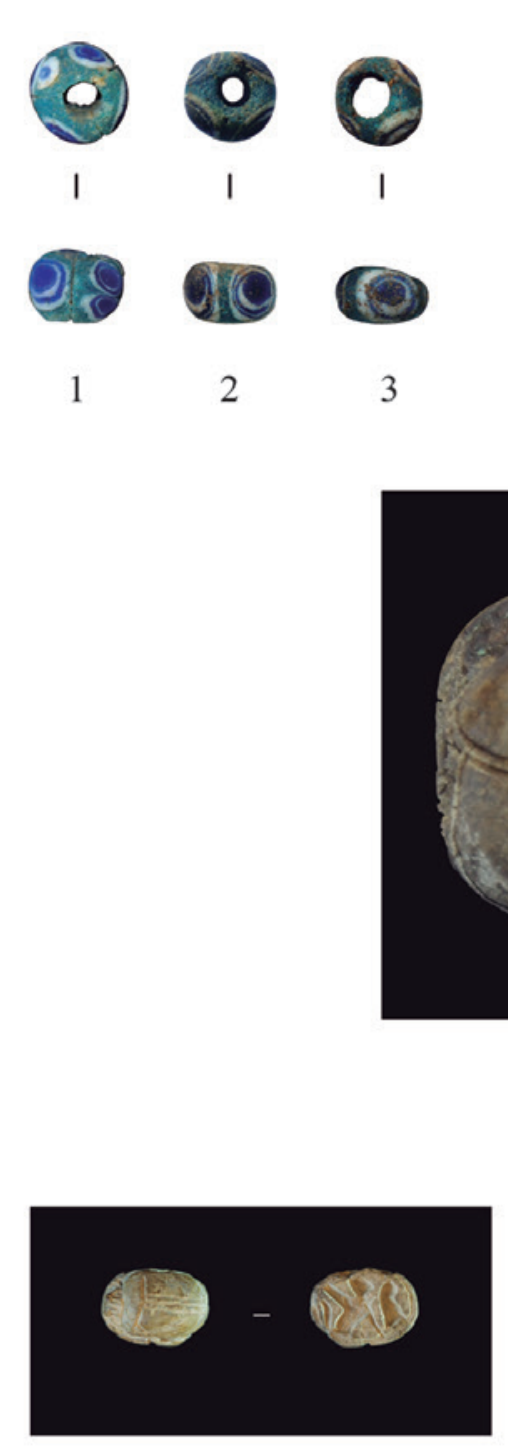

8

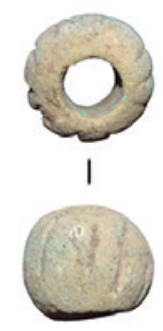

4

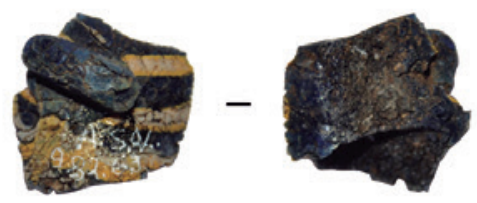

5

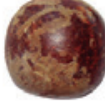

6

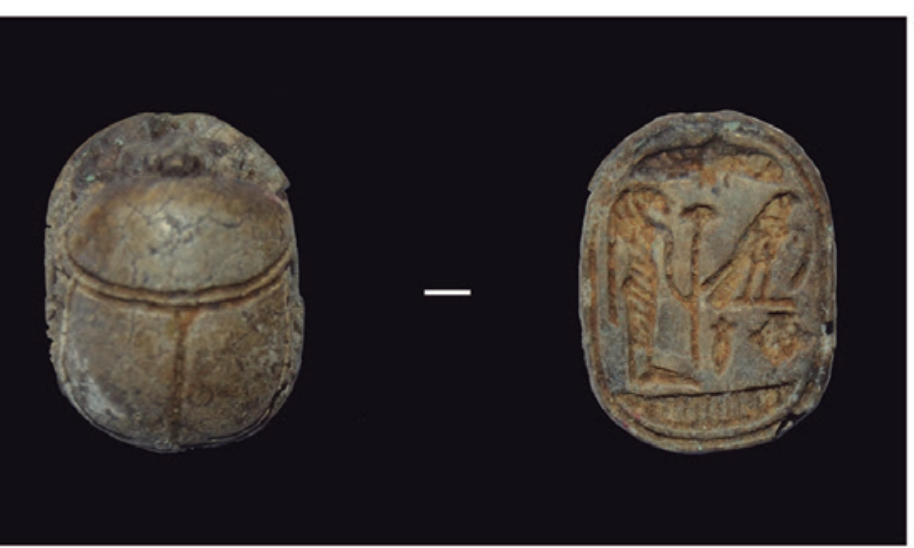

7

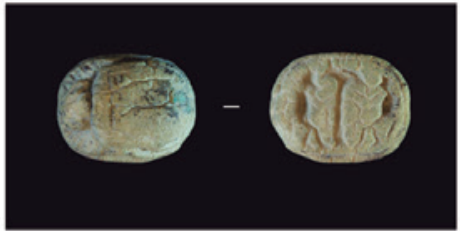

9

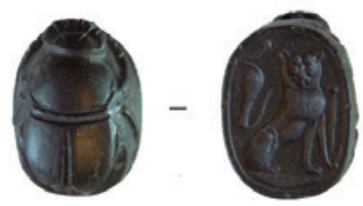

10

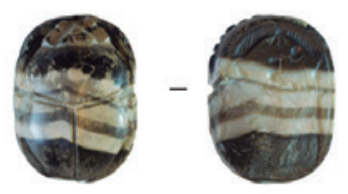

11

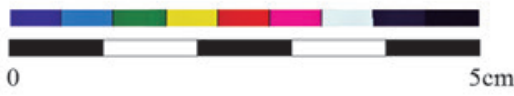

Figura 2 - Exotica do Olival do Senhor dos Mártires (1): 1-3 - contas de colar de vidro; 4 - conta de colar de faiança; 5 - fragmento de recipiente de vidro; 6 - conta de colar de cornalina (?); 7-11 - escaravelhos egípcios / de tipo egípcio. 


\begin{tabular}{|c|c|c|c|c|c|c|c|}
\hline & 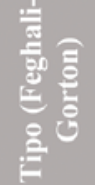 & 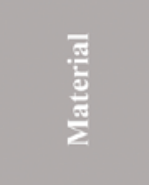 & 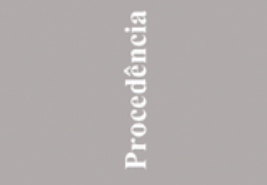 & 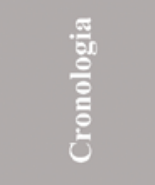 & 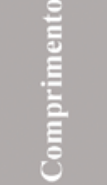 & 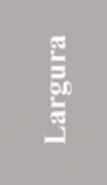 & 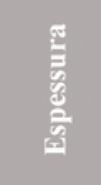 \\
\hline 7 & XIVB & $\begin{array}{c}\text { Pasta } \\
\text { vítrea (?) }\end{array}$ & Naucrátis? & $\begin{array}{c}2^{\mathrm{a}} \mathrm{m} . \mathrm{VII}- \\
\text { i. VI }\end{array}$ & $3,7 \mathrm{~cm}$ & $3,4 \mathrm{~cm}$ & $0,7 \mathrm{~cm}$ \\
\hline 8 & XVI & Espinela & Naucrátis? & VI & $1,15 \mathrm{~cm}$ & $0,82 \mathrm{~cm}$ & $0,6 \mathrm{~cm}$ \\
\hline 9 & $\begin{array}{l}\mathrm{XXC} \\
(\text { simil) }\end{array}$ & $\begin{array}{l}\text { Esteatite } \\
\text { vidrada (?) }\end{array}$ & $\begin{array}{l}\text { Chipre (ou imitação } \\
\text { ocidental)? }\end{array}$ & VII - VI & $1,5 \mathrm{~cm}$ & $1,2 \mathrm{~cm}$ & $0,89 \mathrm{~cm}$ \\
\hline 10 & - & $\begin{array}{l}\text { Quartzo } \\
\text { negro (?) }\end{array}$ & Sardenha (Tharros?) & $\mathrm{V}-\mathrm{IV}$ & $1,9 \mathrm{~cm}$ & $1,4 \mathrm{~cm}$ & $1,1 \mathrm{~cm}$ \\
\hline 11 & - & Ágata & Desconhecida & $\mathrm{V}$ ? & $1,8 \mathrm{~cm}$ & $1,32 \mathrm{~cm}$ & $1 \mathrm{~cm}$ \\
\hline
\end{tabular}

Figura 3 - Escaravelhos egípcios/ de tipo egípcio do Olival do Senhor dos Mártires: principais características (seg. Almagro-Gorbea \& Torres Ortiz, 2009).

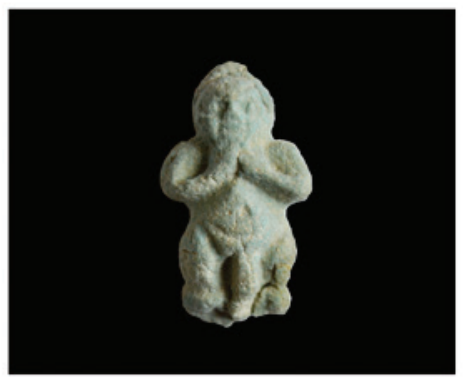

12

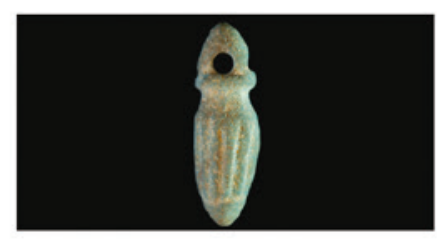

13

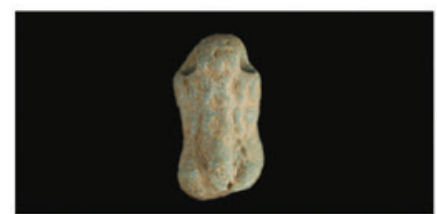

14

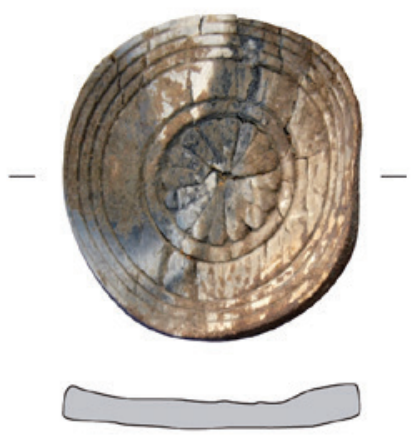

15
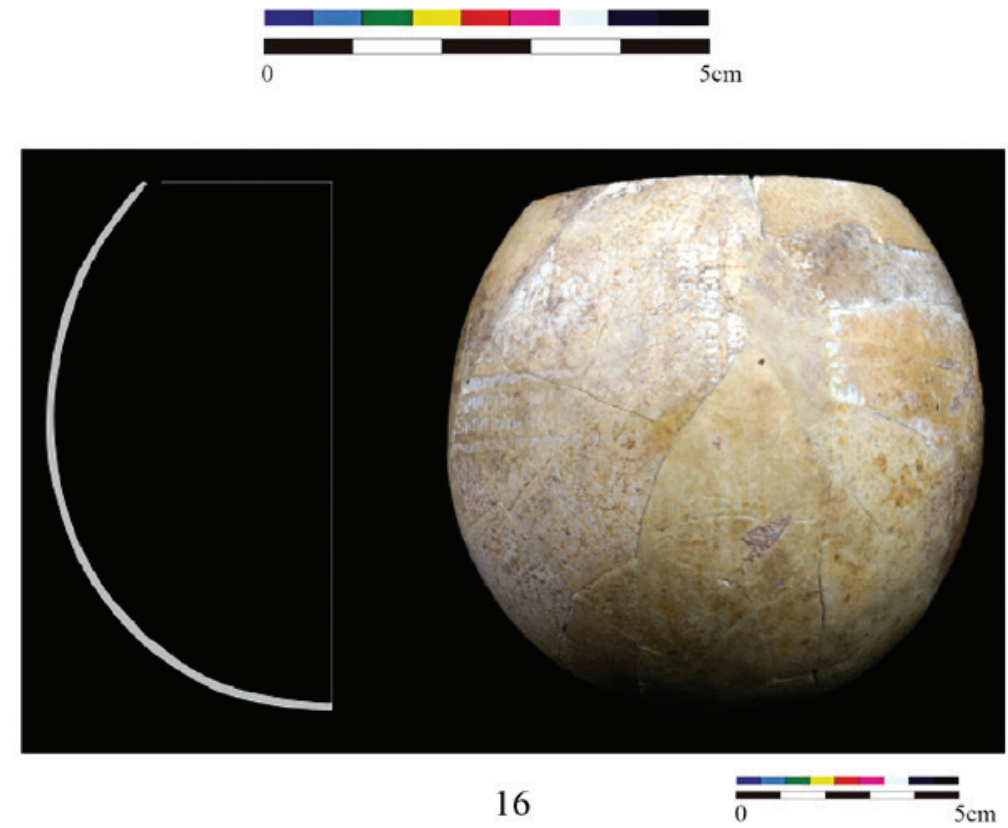

Figura 4 - Exotica do Olival do Senhor dos Mártires (2): 12-14 - amuletos "púnicos”; 15 - roseta de marfim ou osso trabalhado; 16 - recipiente de ovo de avestruz. 


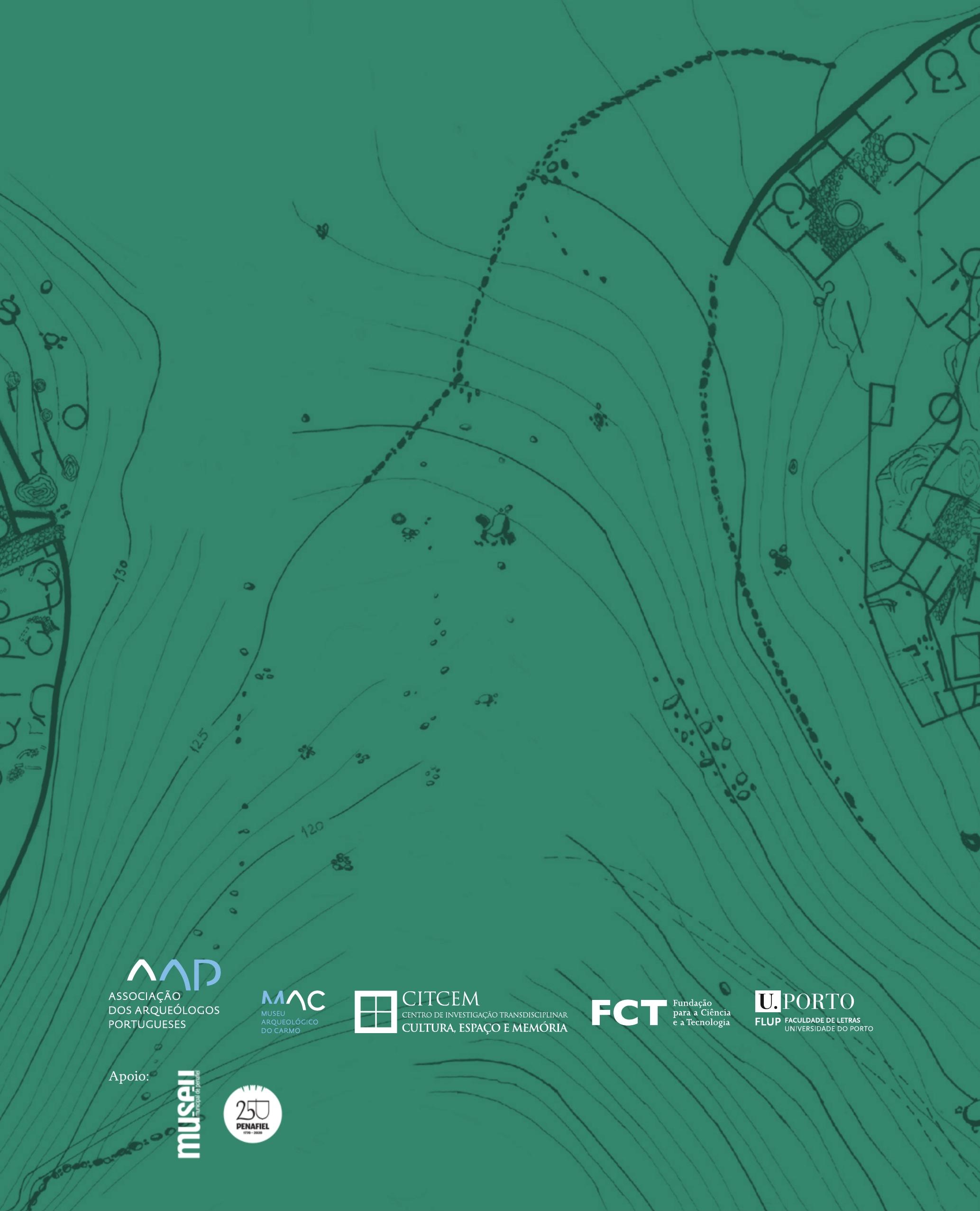

